\title{
Reservoir Quality of Upper Jurassic Corallian Sandstones, Weald Basin, UK
}

\author{
Dinfa Vincent Barshep (1) and Richard Henry Worden*
}

check for updates

Citation: Barshep, D.V.; Worden, R.H. Reservoir Quality of Upper Jurassic Corallian Sandstones, Weald Basin, UK. Geosciences 2021, 11, 446. https://doi.org/10.3390/ geosciences11110446

Academic Editors: R. Douglas Elmore and Jesus Martinez-Frias

Received: 22 September 2021

Accepted: 21 October 2021

Published: 29 October 2021

Publisher's Note: MDPI stays neutral with regard to jurisdictional claims in published maps and institutional affiliations.

Copyright: (c) 2021 by the authors. Licensee MDPI, Basel, Switzerland. This article is an open access article distributed under the terms and conditions of the Creative Commons Attribution (CC BY) license (https:// creativecommons.org/licenses/by/ $4.0 /)$.
Department of Earth, Ocean and Ecological Sciences, University of Liverpool, Liverpool L69 3GP, UK; d.barshep@liverpool.ac.uk

* Correspondence: R.Worden@liverpool.ac.uk

\begin{abstract}
The Upper Jurassic, shallow marine Corallian sandstones of the Weald Basin, UK, are significant onshore reservoirs due to their future potential for carbon capture and storage (CCS) and hydrogen storage. These reservoir rocks, buried to no deeper than $1700 \mathrm{~m}$ before uplift to 850 to $900 \mathrm{~m}$ at the present time, also provide an opportunity to study the pivotal role of shallow marine sandstone eodiagenesis. With little evidence of compaction, these rocks show low to moderate porosity for their relatively shallow burial depths. Their porosity ranges from 0.8 to $30 \%$ with an average of $12.6 \%$ and permeability range from 0.01 to $887 \mathrm{mD}$ with an average of $31 \mathrm{mD}$. The Corallian sandstones of the Weald Basin are relatively poorly studied; consequently, there is a paucity of data on their reservoir quality which limits any ability to predict porosity and permeability away from wells. This study presents a potential first in the examination of diagenetic controls of reservoir quality of the Corallian sandstones, of the Weald Basin's Palmers Wood and Bletchingley oil fields, using a combination of core analysis, sedimentary core logs, petrography, wireline analysis, SEM-EDS analysis and geochemical analysis to understand the extent of diagenetic evolution of the sandstones and its effects on reservoir quality. The analyses show a dominant quartz arenite lithology with minor feldspars, bioclasts, Fe-ooids and extra-basinal lithic grains. We conclude that little compactional porosity-loss occurred with cementation being the main process that caused porosity-loss. Early calcite cement, from neomorphism of contemporaneously deposited bioclasts, represents the majority of the early cement, which subsequently prevented mechanical compaction. Calcite cement is also interpreted to have formed during burial from decarboxylation-derived $\mathrm{CO}_{2}$ during source rock maturation. Other cements include the Fe-clay berthierine, apatite, pyrite, dolomite, siderite, quartz, illite and kaolinite. Reservoir quality in the Corallian sandstones show no significant depositional textural controls; it was reduced by dominant calcite cementation, locally preserved by berthierine grain coats that inhibited quartz cement and enhanced by detrital grain dissolution as well as cement dissolution. Reservoir quality in the Corallian sandstones can therefore be predicted by considering abundance of calcite cement from bioclasts, organically derived $\mathrm{CO}_{2}$ and Fe-clay coats.
\end{abstract}

Keywords: Corallian sandstones; reservoir quality; bioclastic sandstones; early carbonate cementation; shallow reservoirs; berthierine grain-coats; low temperature quartz cement

\section{Introduction}

Diagenesis involves physical, chemical and biological processes which act on texturally and compositionally unstable sediments, causing them to reach mineralogical and textural maturity and converting sediment into rock [1]. Diagenetic processes alter sedimentary rock's porosity and permeability (reservoir quality) as burial progresses [2]. Understanding the controls and processes involved in diagenetic alteration is therefore useful in predicting reservoir quality evolution [3].

Under some circumstances, differences in reservoir properties, such as porosity and permeability, can be linked to variations within their depositional systems [1]. The specific characteristics of primary depositional systems are paramount for reservoir quality 
in shallow reservoirs but they become relatively less important as burial proceeds and as mesogenetic processes become dominant [4]. It therefore follows that, for shallowburied, diagenetically-simple sandstones, understanding the dominant depositional controls (texture and composition) may be sufficient to predict reservoir quality [4]. Near surface (eogenetic) processes represent a continuum during the gradual adoption of a close-packed structure due to compaction and alteration of reactive detrital grains during the first $2000 \mathrm{~m}$ of burial before the onset of deeper-burial related physicochemical adjustments that allow sedimentary rocks to achieve true textural and thermodynamic equilibrium [5]. Understanding the controls on eogenetic processes can permit prediction of reservoir quality in rocks that have not entered the mesogenetic realm. If eogenetic processes, such as early calcite growth, clay coat formation and initial compactional processes, are better understood, then this may permit enhanced prediction of reservoir quality even in more deeply buried rocks that have inevitably undergone eodiagenesis [1,5]. This study of iron-rich and bioclastic Jurassic sandstones at a relatively shallow present-day depth of about 850 to $900 \mathrm{~m}$ (true vertical depth, TVD) in the Weald Basin, UK, sheds light on eogenetic processes.

The onshore Mesozoic Weald Basin, in southeast England, contains many small petroleum accumulations, including the shallow (less than $1000 \mathrm{~m}$ ) Palmers Wood and Bletchingley fields [6-8]. There are many small oil fields on the southern and western flanks of the Weald Basin with a combination of oil and gas fields on the northern flank $[6,8]$. Oil and gas have been produced from Palmers Wood and Bletchingley accumulations, at relatively low flow rates, from Upper Jurassic Corallian Group sandstones since 1983 [6,9]. These sandstone reservoirs represent a combination of quartz- and bioclast-rich, and iron-bearing clastic deposits [10-12]. The producing intervals have overall sandstone thickness of about 9 to $25 \mathrm{~m}$ [12] but they have low production rates, so that a simple sedimentological approach (presence or absence of sand) is insufficient to understand their reservoir quality. Several studies, including Hillis, Holford [13], Hawkes, Fraser [9], Hansen, Blundell [14] and Sellwood, Scott [15], reported on the tectonic evolution, regional geology and hydrocarbon potential $[6,8]$ of the basin but there is little published on diagenesis and its effect on the reservoir quality of Corallian sandstone reservoirs.

Reservoir quality is a key risk factor in hydrocarbon exploration [5,16-18], so that it is important to understand the effects of diagenesis on reservoir quality evolution of sandstones to enable prediction of reservoir quality away from wells. This study aimed to advance the knowledgebase about the controls on reservoir quality of shallow buried reservoir rocks and the potential effects of early diagenesis on subsequent diagenesis. Furthermore, the two structures (Palmers Wood and Bletchingley) are relatively close to London and other populous parts of the south-east of the UK. Considering the proximity of these fields to areas of high demand for energy and the UK's progressive drive to carbonneutrality, it is possible that these old petroleum fields might be re-purposed, as the energy transition progresses, for carbon capture-, compressed air- or hydrogen-storage. Understanding the controls on the distribution of storage (porosity) and injectivity (permeability) in these fields may become increasingly important as the energy transition advances.

This study incorporated conventional oil field data from Bletchingley and Palmers Wood in the northern flank of the Weald Basin. New data were produced on the diagenetic controls on reservoir quality of the Corallian sandstones in order to answer the following research questions:

1. What depositional characteristics have influenced reservoir properties in these Upper Jurassic shallow marine and eogenetically-altered sandstone?

2. What pore-filling, grain-replacive or grain-coating mineral cements are found in these sandstones?

3. How much compaction has occurred in these sandstones?

4. What processes have dominated reservoir quality in these sandstones? 


\section{Geological Background}

\subsection{Regional Geology}

The Weald Basin is bound to the north by the London-Brabant platform, to the south by the Portsdown-Paris Plage ridge (Portsdown-Middleton trend) and the Hampshire-Wessex Basin to the west $[14,19,20]$ (Figure 1). The Weald Basin is underlain by Middle Devonian to Lower Palaeozoic basement rocks which were deformed during the Carboniferous Hercynian Orogeny $[6,14]$. The Hercynian orogeny produced east-west trending fault. These faults underwent reactivation and became the main structural controls on rift basin formation, and the creation of accommodation space, in the Weald area (Figure 1).

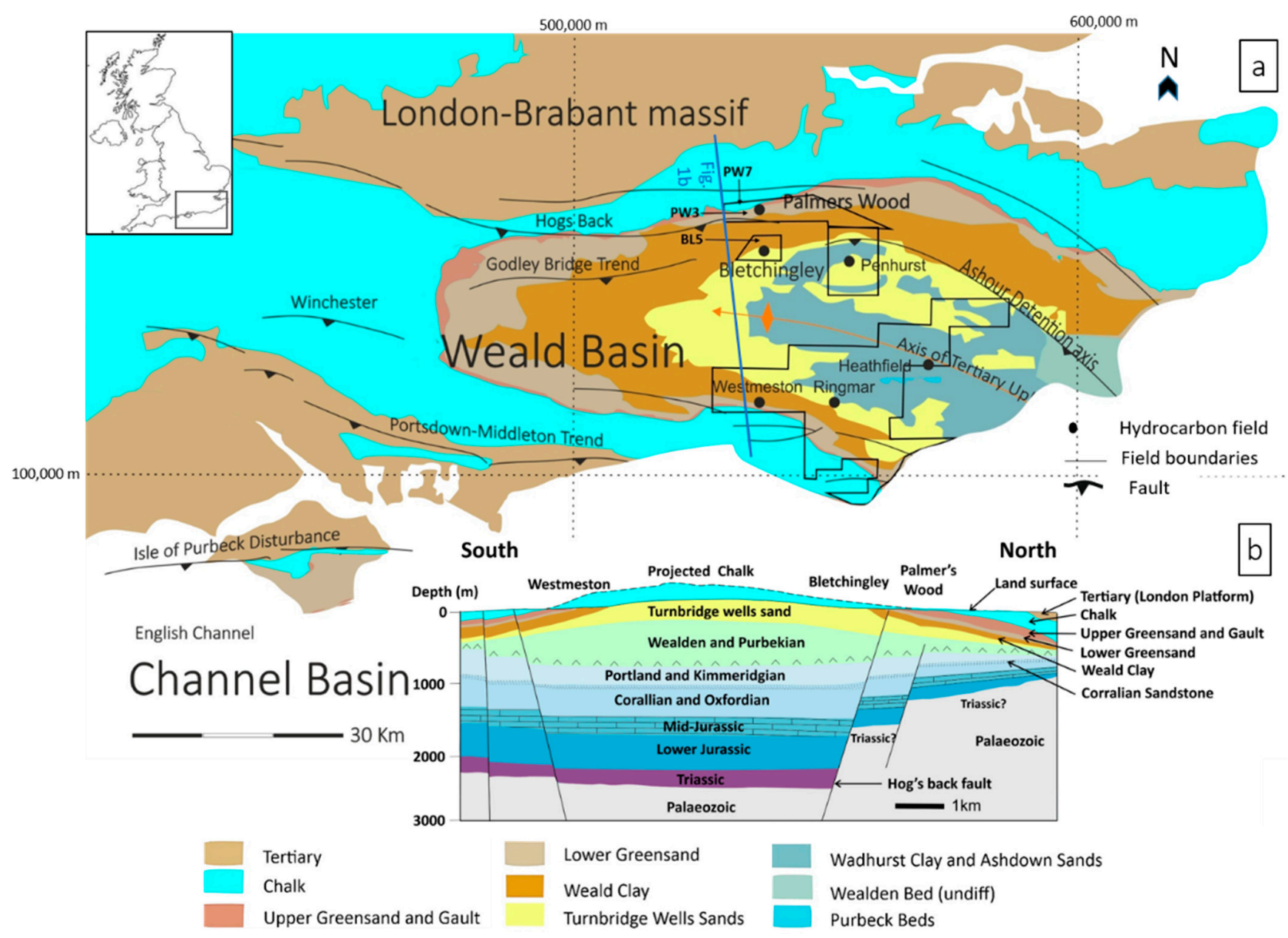

Figure 1. (a) Location map of the Weald Basin showing surface geology with major structural trends (b) Schematic of the subsurface through the line of section in (a) as adapted from Andrews [7]; Butler and Pullan [19].

During the middle part of the Mesozoic, thermal subsidence, associated with block faulting, created accommodation followed by the Lower Jurassic Rhaetic transgression and the subsequent deposition of the Lower Jurassic White Lias, Lower Lias, Middle Lias and Upper Lias units (Figure 2) [7,15,21]. A broad, shallow, carbonate bank developed due to tectonic uplift at the end of the early Jurassic on which Middle Jurassic Bajocian Inferior Oolite and Bathonian Great Oolite were deposited (Figure 2) [7,20-22]. Continued rifting, thermal subsidence and transgression from the Middle Jurassic (Callovian) to Lower Cretaceous caused the deposition of marine mudstones and limestones of the Oxford Clay Formation, Corallian Group, Kimmeridge Clay Formation and Portland Group [14,15]. The deposition of these marine mudstones and limestones was interrupted by the deposition of the coarse clastic Upper Oxfordian (Corallian Group) and Portlandian (Portland sandstone 
Formation) sandstones, which were reported to be sourced from the London Brabant Massif, to the north of the basin [15,19]. The overlying, sabkha-related Purbeck Group was subsequently deposited at the very end of the Jurassic through to the Lower Cretaceous, as relative sea-level fell $[14,19,23]$. This was followed by the deposition of the continental Valanginian Wealden Group clastic sediments [23].

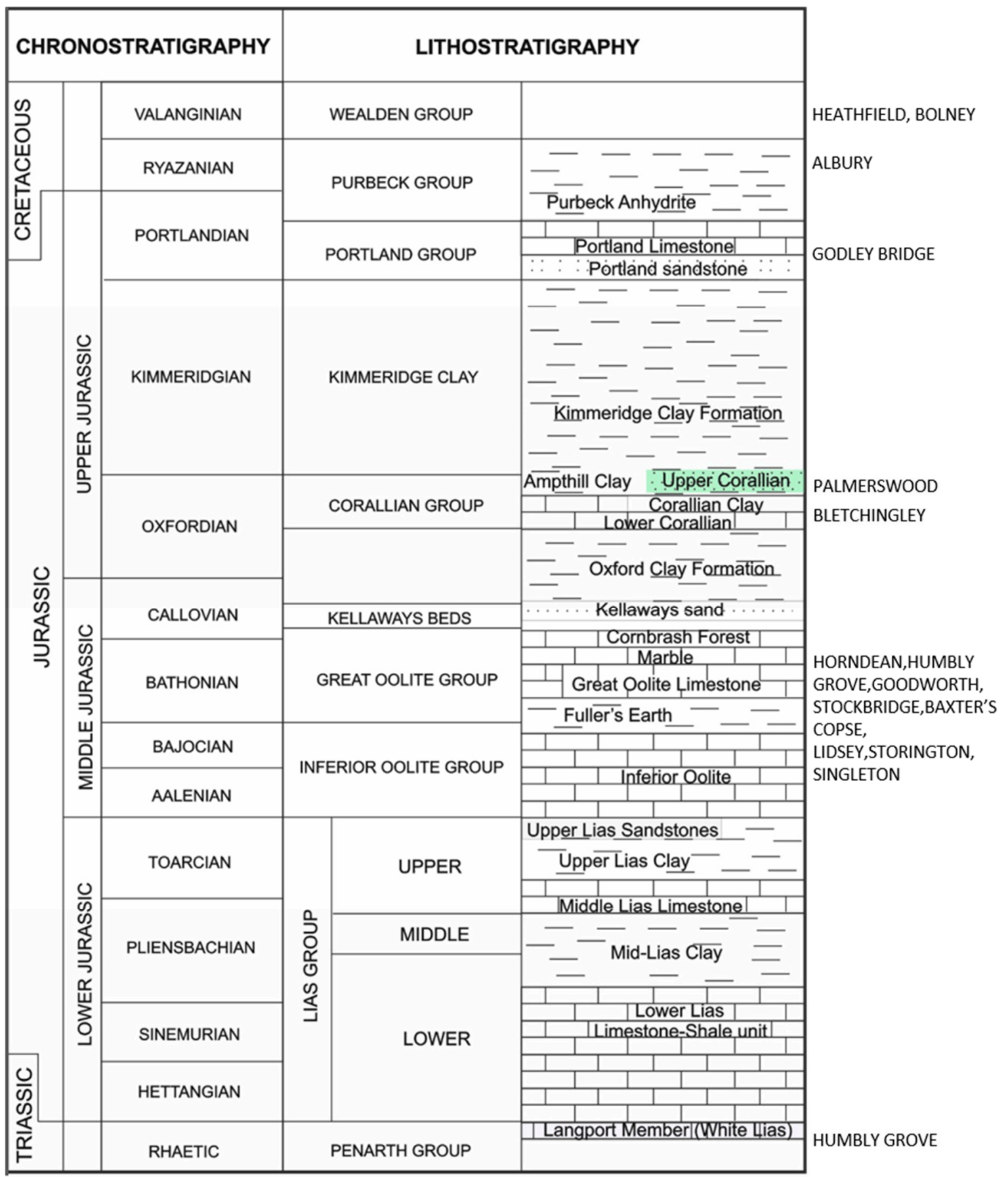

Corallian Sandstone Formation

Figure 2. Generalised stratigraphic section for the Jurassic of the Weald Basin as adapted from [7]. Showing lithologic units as well as selected hydrocarbon fields and their reservoir sections. The Corallian sandstone Formation is highlighted in green. 
Cenozoic fault reactivation and basin inversion occurred in response to compressive forces from the south during the opening of the North Atlantic in the Paleogene, with a second phase in the Miocene possibly associated with the Alpine tectonism [24]. The resulting inversion caused a regional uplift, reported to be as much as $2134 \mathrm{~m}(7000 \mathrm{ft})$ [13] Basin inversion led to the formation of broad, dome-shaped, hanging-wall anticlines (with the London Basin to the north and the Hampshire-Dieppe Basin to the south), subsiding to form flanking basins in the late Paleogene-Eocene [14]. The Cenozoic inversion led to erosion and removal of sediments younger than the Valanginian Wealden Group [15].

\subsection{Trap Formation and Hydrocarbon Occurrence}

The Upper Jurassic to Lower Cretaceous rifting caused the development of extensional trapping geometries, trending east-west along low angle faults, which originated from earlier Variscan thrusts $[9,14]$.

Organic-rich candidate source rocks in the Weald Basin include the Liassic shales [14,19,25], the Oxford Clay Formation and the Kimmeridge Clay Formation $[7,19,25,26]$. It has been suggested that the Lias and Oxford Clay reached the gas generation window in the centre of the Weald Basin while the Kimmeridge Clay may have only reached the oil generation window [26].

Others have suggested that the Lower Jurassic source rocks reached maturity and expelled hydrocarbons in the early Cretaceous $[14,19,25]$. Expulsion of hydrocarbons terminated during Cenozoic fault reactivation, inversion and cooling of source rocks $[9,14]$.

\subsubsection{Bletchingley Field}

The relatively shallow Bletchingley field was discovered in 1963, near the village of Bletchingley, when seismic surveys showed two faulted structures within existing mining leases [6]. The seismic survey resulted in the drilling of four wells between December 1965 and 1966; wells BL1 and BL2 on the eastern flank both tested gas from the Upper Jurassic Corallian limestone with a maximum flow rate of 9.65 MMSCF/day [6]. Gas in place was estimated to be between 1 to 6 BCF [6]. Wells BL5 and BL6 were drilled in 2008 and the Corallian sandstone, the subject of this paper, reportedly flowed at about $250 \mathrm{~b} / \mathrm{d}$ in BL5 at a true vertical depth of about $850 \mathrm{~m}$. Well BL5 was drilled at a low angle so that measured depths (m MD) are significantly greater than true vertical depths (m TVD). In this study, logs and core sample from BL5 have depths reported in terms of the measured depths (m MD).

\subsubsection{Palmers Wood Field}

Similar to Bletchingley, the relatively shallow Palmers Wood field is also a seismicallydefined prospect located on the northern flank of the Weald Basin [6]. In 1983, the first well was drilled at Rook's Nest farm and tested oil at unstable rates of $540 \mathrm{~b} / \mathrm{d}$ from

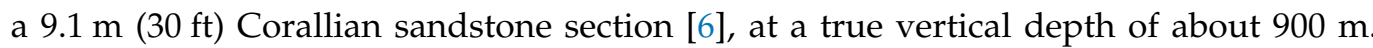
Further testing, in new appraisal wells, from 1984 to the 1990s tested oil [6]. Average porosity is about $17 \%$ with mean permeability ranging from 5 to $7 \mathrm{mD}$, explaining the low production rates. The stock tank oil initially in place (STOIIP) was initially estimated to be 11.73 MMSTB [6].

\section{Materials and Methods}

\subsection{Sedimentary Core Logging}

The sedimentary cores were originally measured in feet, as all well depths (logs and core) were recorded in feet, but the depths have here been converted to metres. High resolution sedimentary core logging of three wells: Bletchingley 5 (BL5), Palmers Wood 3 (PW3) and Palmers Wood 7 (PW7), was carried out at the British Geological Survey (BGS) core store in Keyworth, Nottinghamshire. The wells were logged on a scale of 1:24, recording grain size, lithology, sedimentary structures, bioclasts, ichnofabrics, cementation, 
fractures, hydrocarbon stains and well deviation. About $17 \mathrm{~m}$ of core was available from PW3, 17 m of core was available from PW7 and nearly $20 \mathrm{~m}$ of core was available from BL5.

Ichnofabrics and depositional environments were determined using methods outlined by Hampson and Storms $[27,28]$. Sedimentary logs have been summarised and digitised to a scale of 1:240 and related to wireline and routine core analysis data.

\subsection{Wireline Analysis}

Wireline logs used in this study include neutron logs, density logs and gamma ray logs. Gamma ray logs were used to determine shale proportions (Vshale) using the formula:

$$
\text { Vshale }=\frac{\mathrm{GR}_{\text {meas }}-\mathrm{GR}_{\min }}{\mathrm{GR}_{\max }-\mathrm{GR}_{\min }}
$$

where $G R_{\text {meas }}$ is the measured gamma ray value for the depth of interest, $G R_{\max }$ is the maximum gamma ray log value for the rock section of interest and the minimum gamma ray value for the rock section of interest is denoted by $\mathrm{GR}_{\min }$.

Wireline neutron-density cross-over plots were used to define pay and non-pay zones as is conventional in petrophysical analysis [29]. Core-to-log depth shifts were made to match density log porosity to core analysis porosity and Vshale to mudstones identified during core description.

\subsection{Petrographic Analysis}

Petrographic analysis was carried out to determine mineralogy, modal composition, textural relationships, pore space morphology, and types of cements present, as well as the relative timing of diagenetic events. In this case, 51 polished sections were prepared from plugs used for core analysis from PW7, PW3 and BL5, in the standard manner for water-sensitive plugs. Polished thin sections were used for both optical microscopic examination and SEM analysis. The polished sections were all impregnated with blue-dyed epoxy resin to aid in the characterisation of pores. Light microscopy was undertaken using an Olympus BX51 microscope. In this case, 48 samples were point counted to determine modal composition using an Olympus BX53M microscope fitted with a Conwy Valley systems Petrog stage and software. For point counting, appropriate grid spacing was chosen to enable representative sampling of 300 compositional points with a X10 magnification objective. Attention was paid to cement types, cement stratigraphy and replacive cements to help reveal the order of diagenetic events (i.e., paragenetic sequence). A further 250 points were analysed with a X5 objective to measure grain size and sorting.

Backscattered Scanning Electron Microscopy (BSEM) was carried out using a Hitachi TM3000 table-top SEM. This was undertaken to ascertain mineralogy, mineral/cement growth relationships and textural relationships.

Automated mineralogy data were acquired using SEM-EDS technology developed by FEI [30]; SEM-EDS is a scanning electron microscope (SEM) equipped with high-speed Energy Dispersive X-Ray Spectroscopy detectors (EDS) [31]. SEM-EDS identifies minerals using Species Identification Protocols (SIPs) which represents an extensive mineral chemical database archived in a library $[32,33]$ to produce a quantitative evaluation of mineral proportions. SEM-EDS analysis produces quantitative mineral proportions, grain and pore space morphology and distribution to a minimum resolution of about 1 to $2 \mu \mathrm{m}$ (i.e., equal to the diameter of the smallest beam-sample interaction volume). SEM-EDS analyses were undertaken with a user-defined resolution depending on the level of detail required and analysis time. In this study, SEM-EDS analyses were undertaken at the University of Liverpool, using a tungsten-filament, operating at $15 \mathrm{kV}$, equipped with two Bruker EDS detectors [34]. A minimum spacing of $2 \mu \mathrm{m}$ was used for higher resolution and $20 \mu \mathrm{m}$ spacing resolution was used where average mineralogy was required across a whole polished section.

X-ray diffraction (XRD) analyses were undertaken at the University of Liverpool's Diagenesis Research Group lab. The analysis was carried out using randomly oriented 
powders with a PANalytical X'Pert Pro MPD X-ray diffractometer (Malvern PANalytical, Malvern, UK). Minerals were quantified by the relative intensity ratio (RIR) [35] method using the PANalytical HighScore Plus software. XRD analysis was carried out to determine bulk rock mineralogy with specific interest on identifying berthierine. Presence of berthierine was determined by heating samples to temperature from ambient to $300^{\circ} \mathrm{C}$, $400{ }^{\circ} \mathrm{C}$ and $550{ }^{\circ} \mathrm{C}$.

\subsection{Routine Core Analysis}

Porosity and permeability were measured by industry core laboratories, from one-anda-half-inch diameter core plugs, cleaned in hot refluxing solvents to remove hydrocarbons and residual brines. Helium porosity was determined using a Boyle's Law porosimeter. The porosity of six additional core plugs from PW3 and PW7 was measured at the rock deformation laboratory University of Liverpool using a Quantachrome Pycnometer. Permeability was measured using a nitrogen permeameter, with samples mounted in a "Hassler" type core holder. Permeability was measured using a steady state flow of nitrogen gas through core plugs; flow rate, temperature and differential pressure were recorded and used in conjunction with core dimensions to calculate permeability from Darcy's equation.

\subsection{Burial History Modelling}

Burial history modelling was carried out with BasinMod software, courtesy of Platte River Associates. The stratigraphic data are from well completion reports for BL5, where depths for modelling are reported as true vertical depths subsea (TVDss) in metres and formation tops defined from cuttings, measurement while drilling (MWD) gamma ray and Rate of Penetration (ROP) data. The TVDss were converted to true vertical depths (TVD) in metres to account for surface elevation above mean sea level before burial analysis was carried out. The stratigraphic sections eroded during the Aptian to Turonian (Cenozoic) inversion was modelled using the Dartford area north of the Weald Basin as Upper Cretaceous (Chalk) and Cenozoic deposits above the Weald Clay have been eroded, hence its absence in the vicinity of the two fields in question. The ages of the various stratigraphic intervals were derived from the British Geological Survey's (BGS) lexicon of named rock units [36] and the age for erosion inferred by calculating the duration of erosion from the deposit thicknesses and a maximum erosion rate of $14.7 \mathrm{~m} / \mathrm{Ma}$. The erosion rate was deduced by dividing the total eroded thicknesses by the number of years since erosion started (55 Ma). Bottom-hole temperatures used here were from BL5 well temperature profile as provided in the well report.

\section{Results}

\subsection{Sedimentary Core Logs}

The Corallian Group sandstones are dominated by light grey to brown sandstone, siltstone and minor dark brown to black mudstone (Figure 3). The results from core logging are summarised in Figure 4 and Table 1 . The sandstones are generally well-sorted (Figure 3a,b) with many poorly-sorted argillaceous intervals (Figure 3c,d).

The sandstones have a variety of sedimentary structures which underscore the changing hydrodynamic conditions during deposition (Figure 4). These sedimentary structures include planar cross-bedding, low angle cross-bedding, trough cross-bedding, low angle lamination, mud drapes, massive bedding, and hummocky cross-bedding, lenticular bedding, flaser bedding, cross lamination, current ripple lamination, wave ripple lamination and climbing current ripple lamination (Figure 4). 

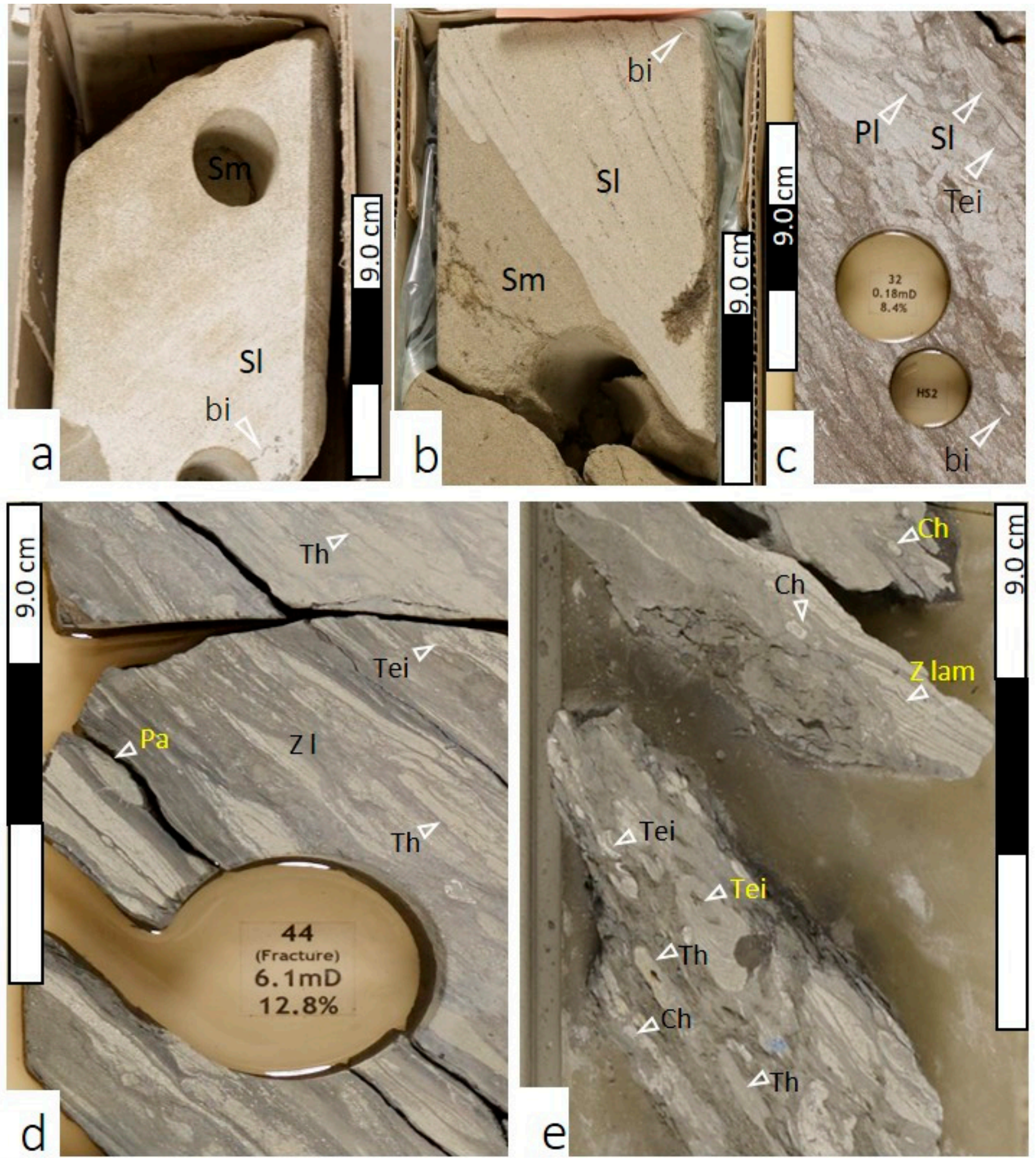

BGS (c) UKRI 2021

Figure 3. Core photographs of facies associations for the Corallian sandstones. All depths are measured depths (m MD) from core, uncorrected for true vertical depth. (a) PW3 (1090.6-1090.7 m MD) showing a foreshore sandstone. (b) is an upper shoreface sandstone from PW7 (1135.2-1135.4 m MD) (c) BL5 (2195.9-2196.1 m MD) is a proximal lower shoreface sandstone. (d) BL5 (2199.4-2199.47 m MD) is a distal lower shoreface sandstone. (e) PW3 (1096.8-1096.9 m MD) shows bioturbated dark mud of the offshore shelf facies association. The cores show an alternation in hydrocarbon stains (brown coloration) in strongly and weakly cemented zones. The core also show that cementation is not closely linked to facies association. Sl: laminated sandstone, Sm: massive sandstone, Zlam: laminated siltstone, Zl: lenticular bedded siltstone, bi: bivalve shell, Pa: Palaeophycus, Tei: Teichichnus, Th: Thalasinoides, Ch: Chondrites, Pl: Planolites. 


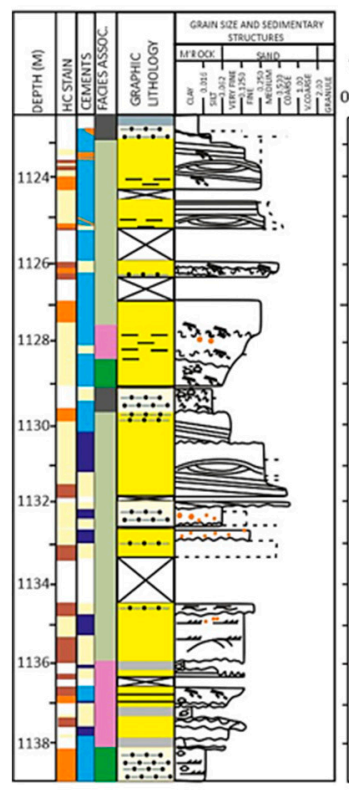

a

Vshale fraction NPHI\% $\mathrm{O}_{\text {porosity }}$ LogPerm (mD)

$0.20 .40 .6 \quad 30 \quad 2010 \quad 0.00 .10 .20 .3-2-1012$
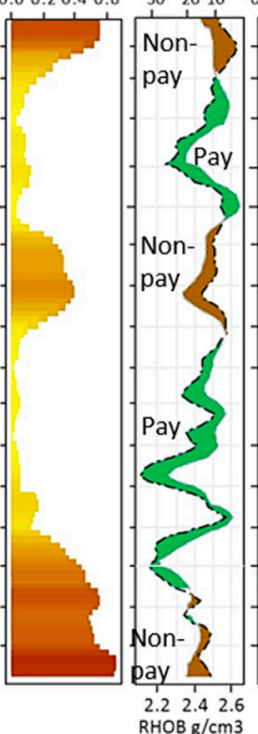

C

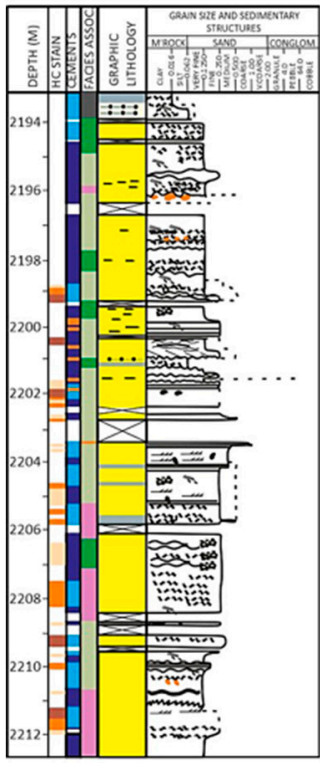

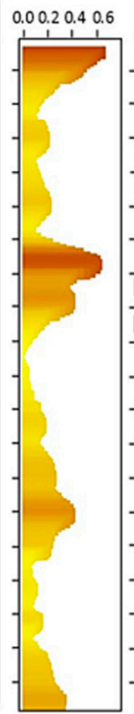

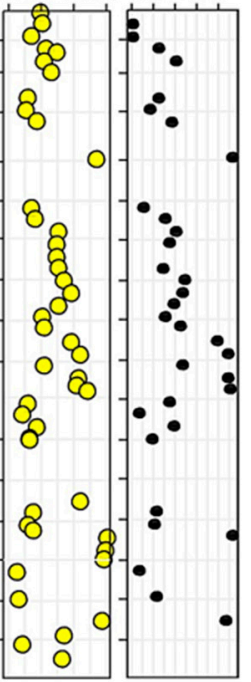

0 porosity

Log Perm (mD)

$0.0 \quad 0.1 \quad 0.2$

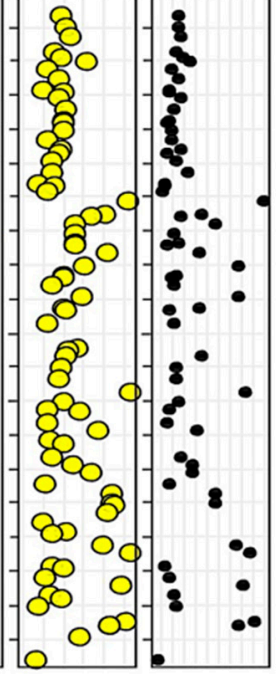

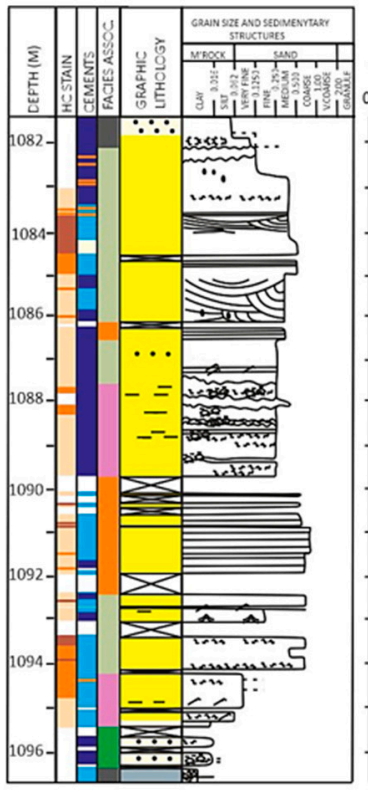

$b$

Vshale fraction NPHI\% $O$ porosity LogPerm (mD) $\begin{array}{llllllllllllll}0.0 & 0.2 & 0.4 & 0.6 & 20 & 10 & 0.0 & 0.1 & 0.2 & 0.1 & 0.3 & 10 & 3.0\end{array}$
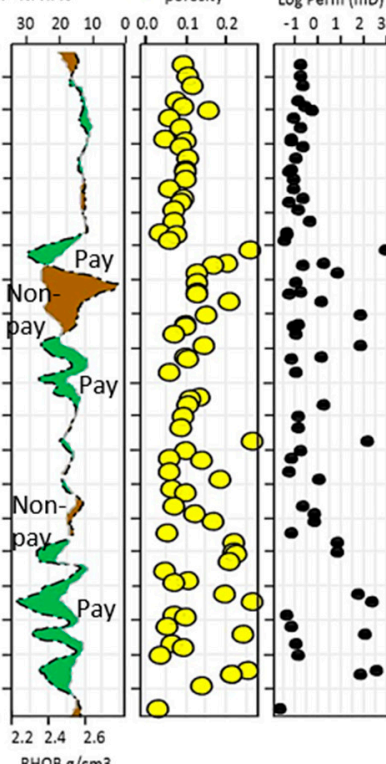

$\mathrm{RHOB} \mathrm{g} / \mathrm{cm} 3$
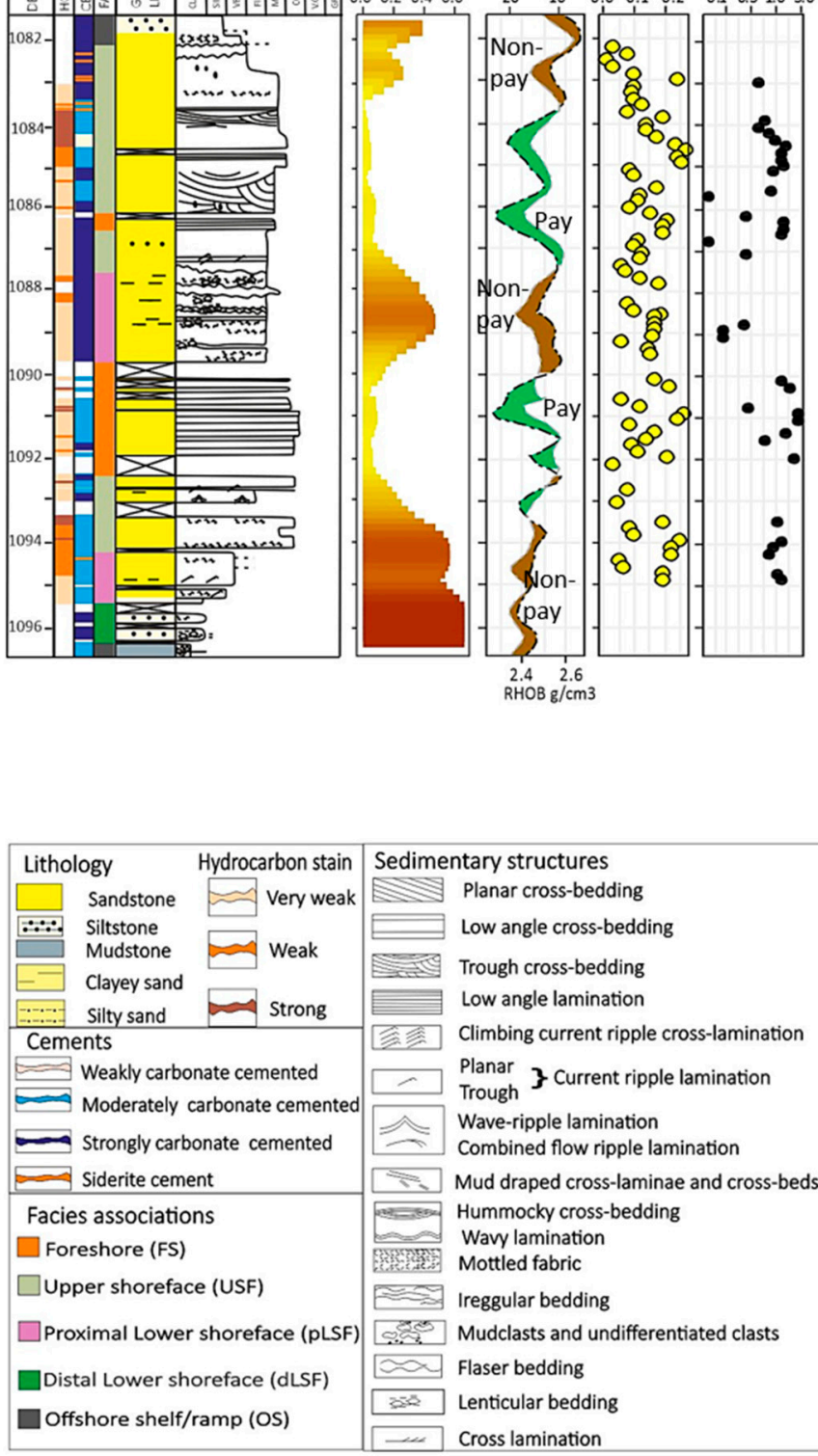

Figure 4. Shows sedimentary log, Vshale log, neutron (NPHI) and density (RHOB) cross-over plot, core analysis porosity $\log$ and core permeability log for wells, (a) PW7, (b) PW3, and (c) BL5. Sedimentary logs show short-range heterogeneity in sedimentary structures and intensity of cementation. They also show variation in hydrocarbon stains with depth. The wireline logs (Vshale, NPHI and RHOB) track the variation in shale content from the sedimentary logs with the core porosity and permeability logs showing the best reservoir quality sections in the sand-rich portions of the logs. Even though the logs show the highest porosity and permeability in the sandier zones. They also have low porosity and permeability in the sandier zones suggesting that lithology is not the dominant control on reservoir quality. The intervals with high calcite cement and clay content show lower porosity and permeability giving an initial indication of possible reservoir quality controls. 
Table 1. Facies association for the Corallian sandstones.

\begin{tabular}{|c|c|c|}
\hline $\begin{array}{c}\text { Facies } \\
\text { Association }\end{array}$ & Lithology and Sedimentary Structures & Bioturbation \\
\hline 1. Foreshore (FSFA) & $\begin{array}{l}\text { Fine to medium-grained low angle } \\
\text { planar-parallel laminated sandstone. } \\
\text { Commonly highly cemented. }\end{array}$ & $\begin{array}{l}\text { Mostly absent. Rare } \\
\text { Macaronichnus if } \\
\text { present. }\end{array}$ \\
\hline $\begin{array}{l}\text { 2. Upper shoreface } \\
\text { (USFA) }\end{array}$ & $\begin{array}{l}\text { Consists of upper-fine to } \\
\text { medium-grained sandstone making up } \\
\text { low angle cross beds, trough and tabular } \\
\text { cross-beds with minor planar lamination } \\
\text { and hummocky cross-stratification. } \\
\text { Cementation is variable. }\end{array}$ & $\begin{array}{l}\text { Sparse to moderate } \\
\text { (Skolithos, Ophiomorpha, } \\
\text { Cylindrichnus, } \\
\text { Planolites some } \\
\text { Anchonichnus and } \\
\text { Macaronichnus). }\end{array}$ \\
\hline $\begin{array}{l}\text { 3. Proximal lower } \\
\text { shoreface (pLSFA) }\end{array}$ & $\begin{array}{l}\text { Very-fine to fine-grained amalgamated } \\
\text { sandstone beds comprised of current } \\
\text { ripple lamination, wave ripple } \\
\text { cross-lamination with some mud-drapes. } \\
\text { Cementation is variable. }\end{array}$ & $\begin{array}{l}\text { Moderate to intense } \\
\text { (Arenicolites, } \\
\text { Anconichnus, } \\
\text { Palaeophycus, } \\
\text { Rhizocorallium, } \\
\text { Ophiomorpha some } \\
\text { Teichichnus rectus, } \\
\text { Cyclindrichnus, } \\
\text { Thalasinoides and } \\
\text { Chondrites). }\end{array}$ \\
\hline $\begin{array}{l}\text { 4. Distal lower shoreface } \\
\text { (dLSFA) }\end{array}$ & $\begin{array}{l}\text { Comprised of clayey siltstone and } \\
\text { sandstone with some fine-grained and } \\
\text { minor medium-grained sand. Beds are } \\
\text { non-amalgamated with flaser bedding, } \\
\text { minor wavy lamination and wave ripple } \\
\text { cross-lamination. Cementation is } \\
\text { variable. }\end{array}$ & $\begin{array}{l}\text { Moderate to intense } \\
\text { (Chondrites, Teichichnus } \\
\text { rectus, Rosellia, } \\
\text { Planolites, Palaeophycus, } \\
\text { Rhizocorallium, } \\
\text { Terebellina, } \\
\text { Ophiomorpha, } \\
\text { Arenicolites and } \\
\text { Thalasinoides). }\end{array}$ \\
\hline $\begin{array}{l}\text { 5. Offshore shelf/ramp } \\
\text { (OSFA) }\end{array}$ & $\begin{array}{l}\text { Consists of mudstone, silty mudstone, } \\
\text { siltstone with some beds of very fine-to } \\
\text { upper fine-grained sandstone. Current } \\
\text { ripple lamination, wave ripple } \\
\text { lamination, sand-mud heterolithics beds. } \\
\text { Cementation is variable. }\end{array}$ & $\begin{array}{l}\text { Intense (Cylindrichnus, } \\
\text { Chondrites, Paleophycus, } \\
\text { Terebellina, Planolites, } \\
\text { Teichichnus zig-zag, } \\
\text { Thalasinoides, } \\
\text { Teichichnus rectus some } \\
\text { Rhizocorallium). }\end{array}$ \\
\hline
\end{tabular}

The core is locally bioturbated. Bioturbation is most evident in argillaceous intervals (Figure 3d,e) but it also homogenises sandy and clay-rich intervals (Figure 3d). Ichnofabrics present include Thalasinoides, Teichichnus, Planolites and Chondrites (Figure 3). Rhizocorallium, Diplocraterion, Rosellia, Palaeophucus, Skolithos and Ophiomorpha.

Centimetre-scale thin beds are common in the Corallian sandstones. From lithology, sedimentary structures and bioturbation, 12 discrete facies have been identified, that group into five facies associations, based on the classification by Hampson and Storms [27] and listed below. In order of reducing depositional energy, the facies associations described in Table 1 are: (1) foreshore facies association (FSFA), (2) upper shoreface facies association (USFA), (3) proximal lower shoreface facies association (pLSFA), (4) distal lower shoreface facies association (dLSFA), (5) offshore/ ramp facies association (OSFA).

The core is locally hydrocarbon stained. Sandstones typically react with hydrochloric acid indicating the occurrence of calcite, present as both recognizable bioclasts and in cemented intervals. Calcite cementation is of variable intensity, hydrocarbon staining is most intense where calcite cement seems to be least abundant (Figures 3 and 4 ) and weak or no hydrocarbons staining occurs in intensely cemented areas (Figure 4a PW3 $1135.0 \mathrm{~m}$ MD and Figure 4c BL5 2195.0-2199.0 m MD). 


\subsection{Wireline Analysis}

The Vshale log (derived using Equation (1)) reveals the presence of radioactive clay mineral zones as well as the presence of non-radioactive, sand-dominated reservoir sections in the Corallian sandstones (Figure 4). The neutron-density cross-over plot [29] typically is assumed to differentiate pay from the non-pay intervals (Figure 4). There is good agreement between the Vshale logs and the neutron-density cross-over diagram. However, not all the net-sand intervals show the wide separation in neutron-density cross-over typical of pay zones (e.g., BL5, Figure 4c, 2204.0-2206.0 m MD, 2194.0-2197.0 m MD). This suggests that the presence of sand is not the only determinant of pay and non-pay zones.

\subsection{Routine Core Analysis Porosity and Permeability}

Core porosity and permeability seem to show a good relationship with each other (Figures $4 a-c$ and $5 a)$. The whole of the cored section, including sandstones and much finer-grained lithologies from BL5, has a porosity range of 2.7 to $26.6 \%$ with a mode of $10 \%$ and with values skewed towards the lower porosity range (Figure $5 \mathrm{a}$ ). Core from BL5 has a permeability range of 0.02 to $887 \mathrm{mD}$ with a mode of $0.08 \mathrm{mD}$ (Figure $5 \mathrm{c}$ ). Core from PW3 has a porosity range of 0.8 to $23.1 \%$ with bimodal porosity with modes at $9.4 \%$ and $18.5 \%$ (Figure $5 \mathrm{~b}$ ). PW3 has a permeability range of 0.01 to $508 \mathrm{mD}$ and a mode $0.95 \mathrm{mD}$ (Figure 5c). Core from PW7 has a porosity range of 2.6 to $30 \%$ with a mode of $10.5 \%$ (Figure $5 b$ ) and a permeability range of 0.01 to $401 \mathrm{mD}$ (Figure 5c). PW7 has bimodal permeability with modes at $0.1 \mathrm{mD}$ and $4 \mathrm{mD}$ (Figure $5 \mathrm{c}$ ).
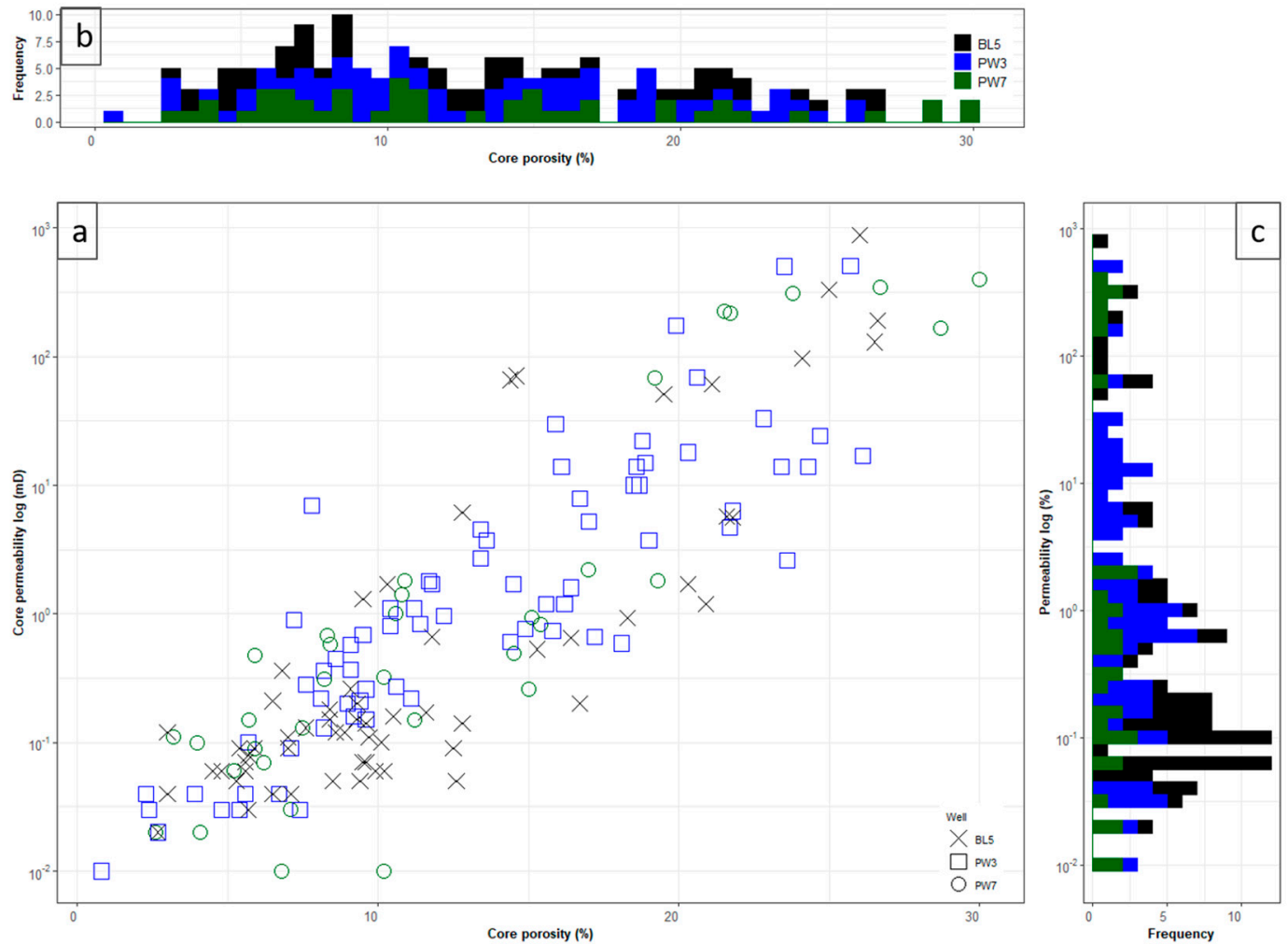

Figure 5. Show a scatter plot with porosity vs. permeability on a scatter plot (a). Margins of the scatter plot shows histograms of porosity (b) and permeability (c). The scatter plots show good porosity and permeability relationship with permeability spread locally over two orders of magnitude suggesting other controls on permeability apart from porosity.

The highest porosity intervals (up to $30 \%$ core analysis porosity) are in sandstone intervals (e.g., Figure 4a PW7 1126.0 m MD, Figure 4b PW3 1084.5 m MD and Figure 4c BL5 $2204.6 \mathrm{~m}$ MD) but relatively high porosity (up to $18 \%$ core porosity) also occurs in argillaceous intervals (Figure 4c BL5 2205.8 m MD). The highest permeability sections 
are all in sandstone intervals (Figure 4a PW7 1125.6 m MD, Figure 4b PW3 1084.3 m MD and, Figure 4c BL5 $2204.6 \mathrm{~m} \mathrm{MD),} \mathrm{which} \mathrm{also} \mathrm{corresponds} \mathrm{to} \mathrm{the} \mathrm{pay} \mathrm{zones} \mathrm{in} \mathrm{the} \mathrm{neutron-}$ density crossover plots. There are also low porosity and low permeability sections in the sandstone intervals (Figure 4a PW7 1125.0 m MD Figure 4a PW7 1135.0 m MD, Figure 4c 2193.0-2197.0 m MD) suggesting that lithology is not the only control on sandstone porosity and permeability. In addition, permeability varies over two orders of magnitude for a given porosity (Figure 5a) suggesting that permeability is affected by factors other than porosity.

\subsection{Petrography}

\subsubsection{Detrital Composition and Fabric}

The Corallian sandstones are composed of moderately- to moderately well-sorted quartz arenites with dominant quartz $(\mathrm{Q})$ grains and minor feldspar $(\mathrm{F})$ and lithic $(\mathrm{L})$ grains. The proportion of quartz to feldspars and lithic grains is in the range of 83.2 to $99.5 \%$, with an average composition of $\mathrm{Q}_{94} \mathrm{~F}_{3} \mathrm{~L}_{3}$ (Figure 6).

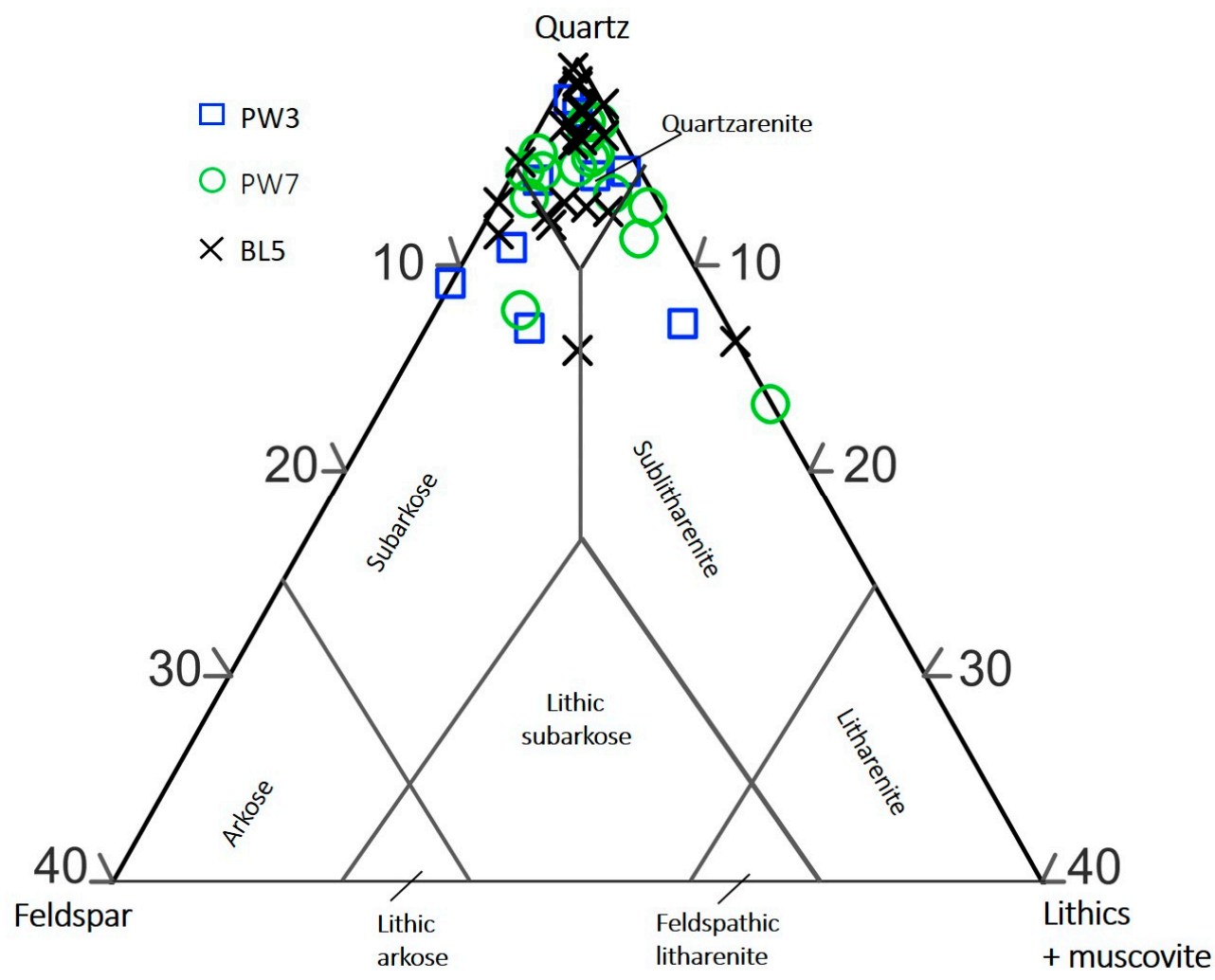

Figure 6. Modal composition for the Corallian sandstones, after McBride [37] showing predominantly quartz arenite lithology.

Point count grain size analysis revealed fine- to medium-grained, subrounded to rounded sand grains (Figures 7-10), with grains either separated from each other in a loosely compacted fabric (Figures $7 \mathrm{a}$ and $11 \mathrm{~b}$ ), or with pores filled with cement (Figures $7 b, 8 a, d$ and 11a). Close-packed framework grain structures are absent (Figure 10a) and there is no evidence of stylolites, suggesting that advanced compaction has occurred. 

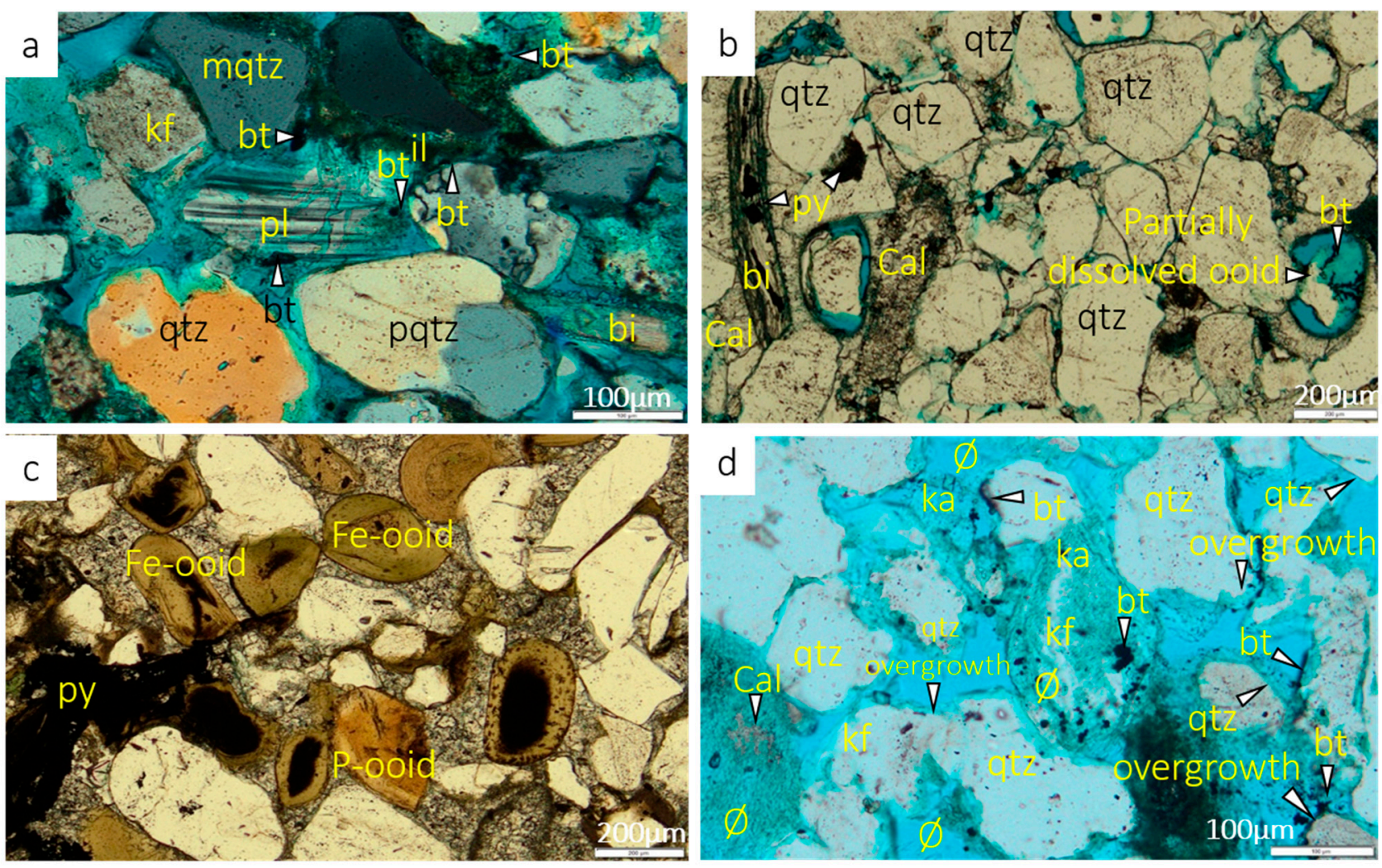

Figure 7. Photomicrographs showing framework grains, minor grains, cement types and porosity for the Corallian sandstones. (a) BL5 (2211.63 m MD) is a cross-polarised photomicrograph showing a dissolved plagioclase feldspar (centre-left), polycrystalline quartz, monocrystalline quartz and bivalve shell in an open-framework grain texture. (b) PW3 (1091.4 m MD): shows a highly cemented rock with bivalve shells replaced by pyrite as well as neomorphosed into calcite cement. The circular pores at the centre-right and centre-left are typical of dissolved ooids. (c) BL5 (2199.9 m MD): shows a highly cemented sandstone with Fe-ooids, phosphate ooids and framework quartz cemented by pyrite and calcite cement. Some of the Fe-ooids-e.g., top-left show signs of abrasion suggesting mechanical breakdown from transport. (d) BL5 (2199.09 $\mathrm{m} \mathrm{MD):} \mathrm{is} \mathrm{a} \mathrm{high} \mathrm{porosity} \mathrm{sandstone} \mathrm{(QEMSCAN} \mathrm{porosity} 20.76 \%$ ) showing extensive grain dissolution with intergranular porosity between grains as well as moldic and microporosity from dissolved grains. The photomicrograph also shows dissolved calcite cement (bottom-left). The feldspar grains have been intensely dissolved and altered to kaolinite with bitumen present within the altered feldspar grains (centre and bottom-right). Bitumen also is also shown lining quartz overgrowths (bottom-left) suggesting that hydrocarbon charge post-dated quartz cementation. Inclusions of bitumen in the micropores as well as at the edge of kaolinite at the top-left suggest some contemporaneous hydrocarbon charge and kaolinite precipitation. Definition of abbreviations used on the images: plagioclase feldspar (pl), k-feldspar (kf), polycrystalline quartz (pqtz), monocrystalline quartz (mqtz), quartzite (qte), iron ooid (Fe-ooid), phosphate ooid (P-ooid) bivalve shell (bi), bitumen (bt), echinoderm (ech), foraminifera (fm), pyrite (py). 

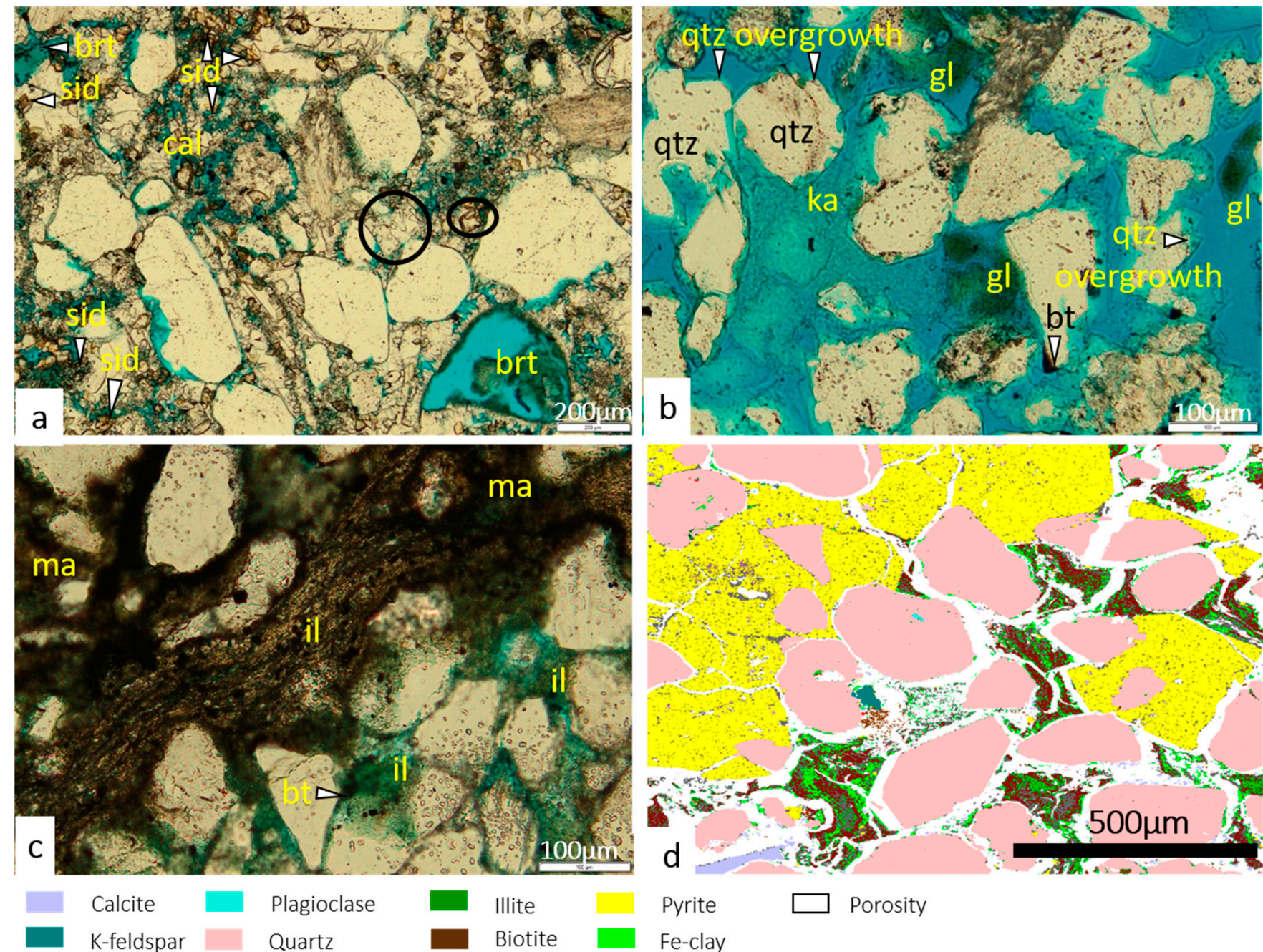

Pyrite $\square$ Porosity

Fe-clay

Figure 8. (a) is a photomicrograph from PW7 (1130.05 m MD) showing calcite cement, siderite filling moldic pores from Fe-ooid dissolution (bottom-left), berthierine replacing an Fe-ooid (bottom-right) and pore-filling dolomite (circled in black). (b) PW7 (1136.52 m MD): is a high intergranular porosity sample with authigenic illite and kaolinite in pore spaces. Quartz overgrowths project from grain surfaces into pore spaces thereby reducing porosity. (c) BL5 (2206.8 m MD): muscovite replaced by illite with pore-filling illite at the bottom centre. (d) PW7 (1123.19 m MD): is an SEM-EDS image with pore-filling pyrite and Fe-clay in a biotite rich matrix. The biotite and Fe-clay occur together which might suggest a genetic relationship. Definition of abbreviations used on the images: quartz grain (qtz), glauconite (gl), calcite cement (cal), siderite (sid), berthierine (brt), illite (il), kaolinite (ka), glauconite (gl), matrix (ma). 

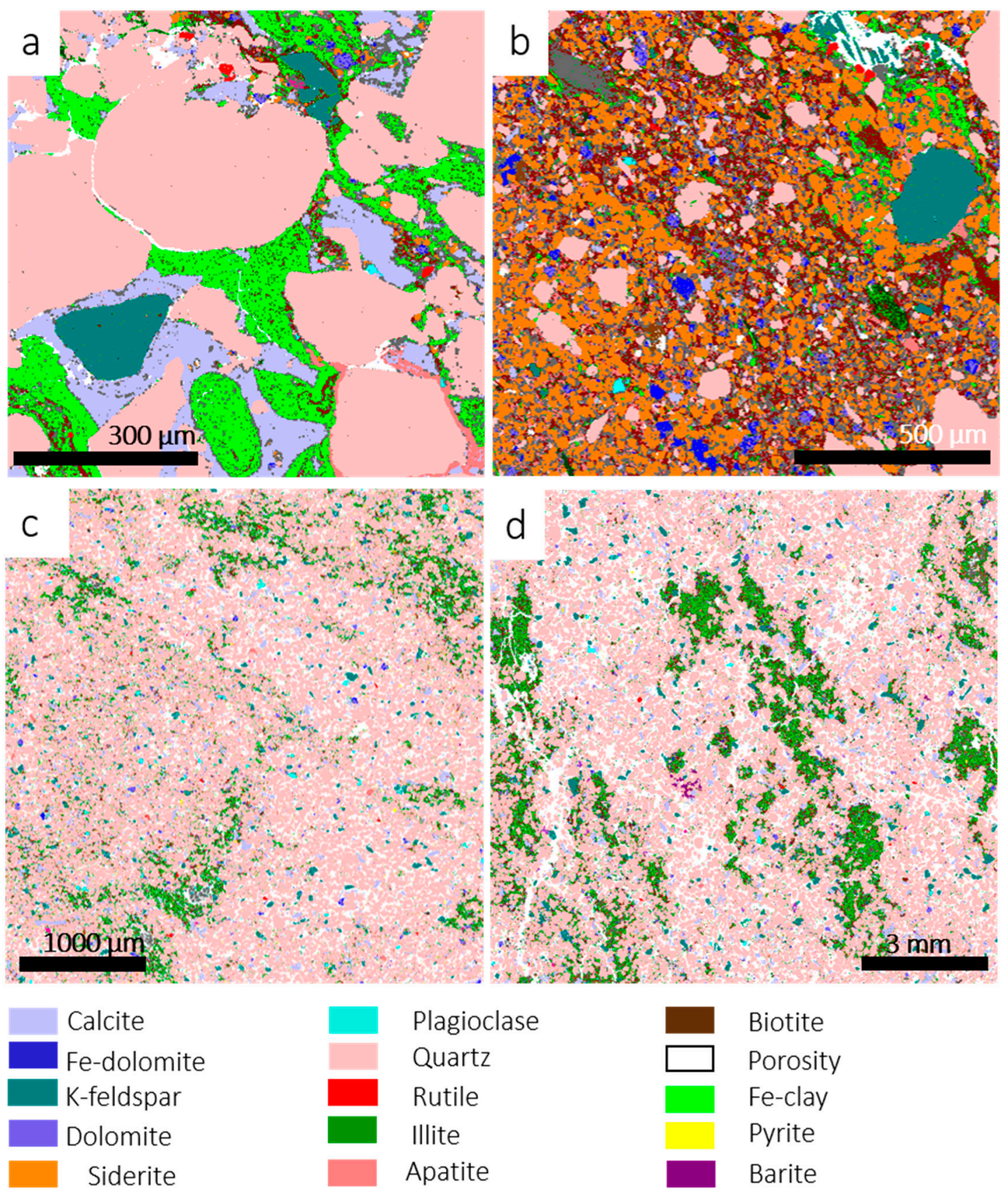

Figure 9. (a) BL5 (2199.9 m MD) at $2 \mu \mathrm{m}$ resolution: SEM-EDS porosity (1.67\%) shows dissolved K-feldspar with the former grain boundaries outlined where calcite cement has filled the dissolved grain portion (bottom-left). Pore-filling apatite is seen at the bottom-right lining a quartz grain. (b) Same sample as Figure 9a, non-bioturbated upper shoreface sandstones. Siderite matrix occupies most of the image truncated by Fe-dolomite and detrital biotite. The top-right shows moldic porosity from a dissolved K-feldspar grain. (c) BL5 (2208.0 m MD): SEM-EDS porosity 19.7\%, core porosity 21.6 , permeability $5.7 \mathrm{mD}$, sandstone sampled from a zone homogenised by bioturbation. (d) PW7 (1135.7 m MD) at $20 \mu \mathrm{m}$ resolution: core porosity $29.6 \%$ showing microfractures. 

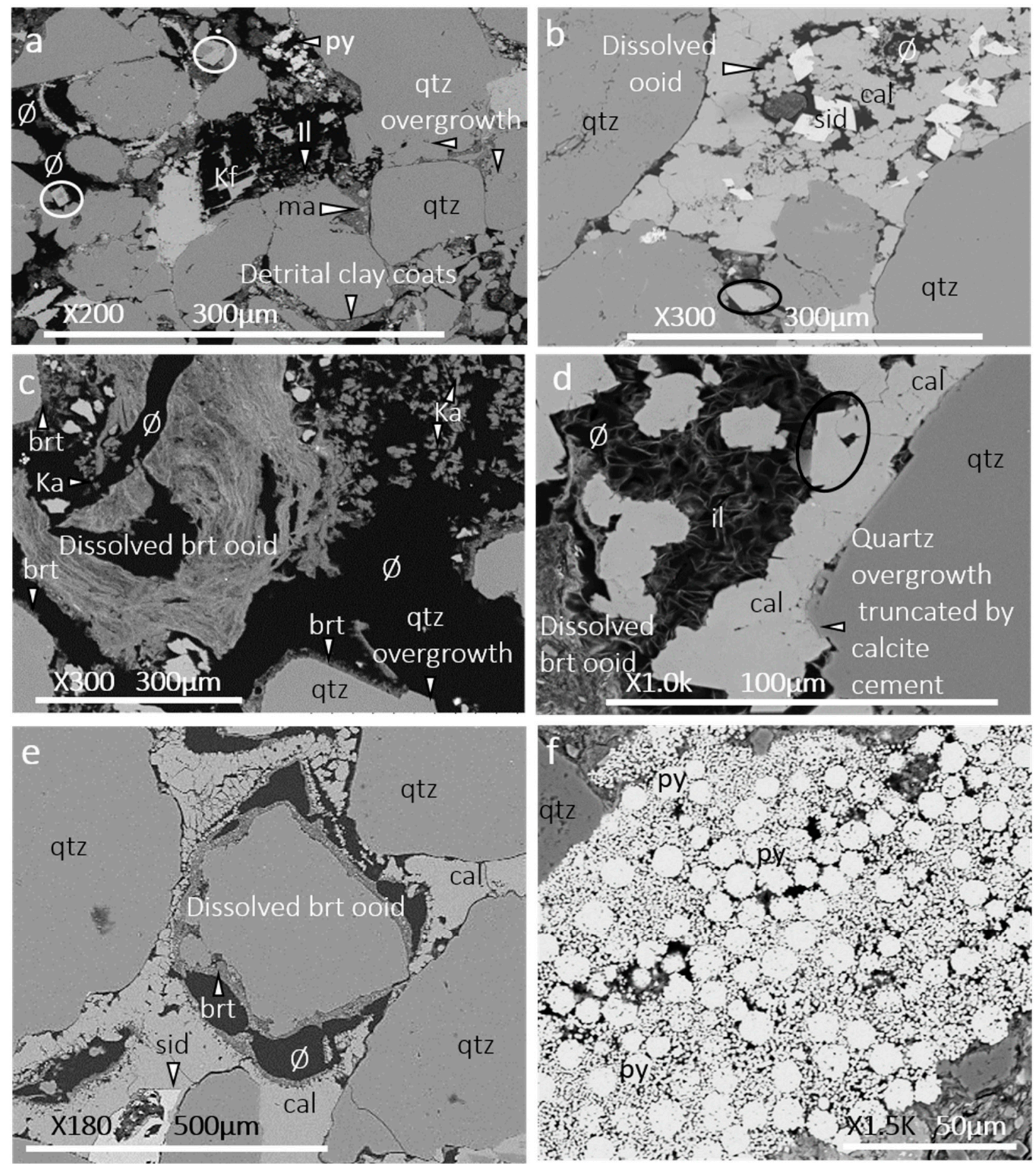

Figure 10. (a) BL5 (2211.6 m MD): altered K-feldspar (centre) and dissolved Fe-ooid (top-left) with some compaction to the top-left. Grain contacts show close-packing texture at the centre-right adjacent to detrital clays. (b) PW3 (1091.4 m MD): shows where calcite and siderite have replaced a dissolved ooid (top) with the relic of the ooid still visible at the top-right and bottom-left corners of the dissolved grain outline. (c) PW3 (1085.1 m MD): relics of a Fe-ooid can be seen in the middle of the photomicrograph while about $30 \mu \mathrm{m}$ thick berthierine coats quartz grains to the centre-right, bottom and bottom-left. Kaolinite filled intergranular pore space to the top-right. (d) PW3 (1085.1 m MD): pore filling illite can be seen in the centre of the photomicrograph with quartz overgrowths overlying a detrital quartz grain. (e) BL5 (2202.2 m MD): dissolved Fe-ooid with relic of cortice forming grain coat. (f) PW3 (1098.3 m MD): pore-filling framboidal pyrite aggregates. Definition of abbreviations used on the images: quartz grain (qtz), K-feldspar grain (kf), berthierine (brt), matrix (ma), calcite (cal), siderite (sid), kaolinite (Ka), illite (il), pyrite (py), porosity (Ø). 

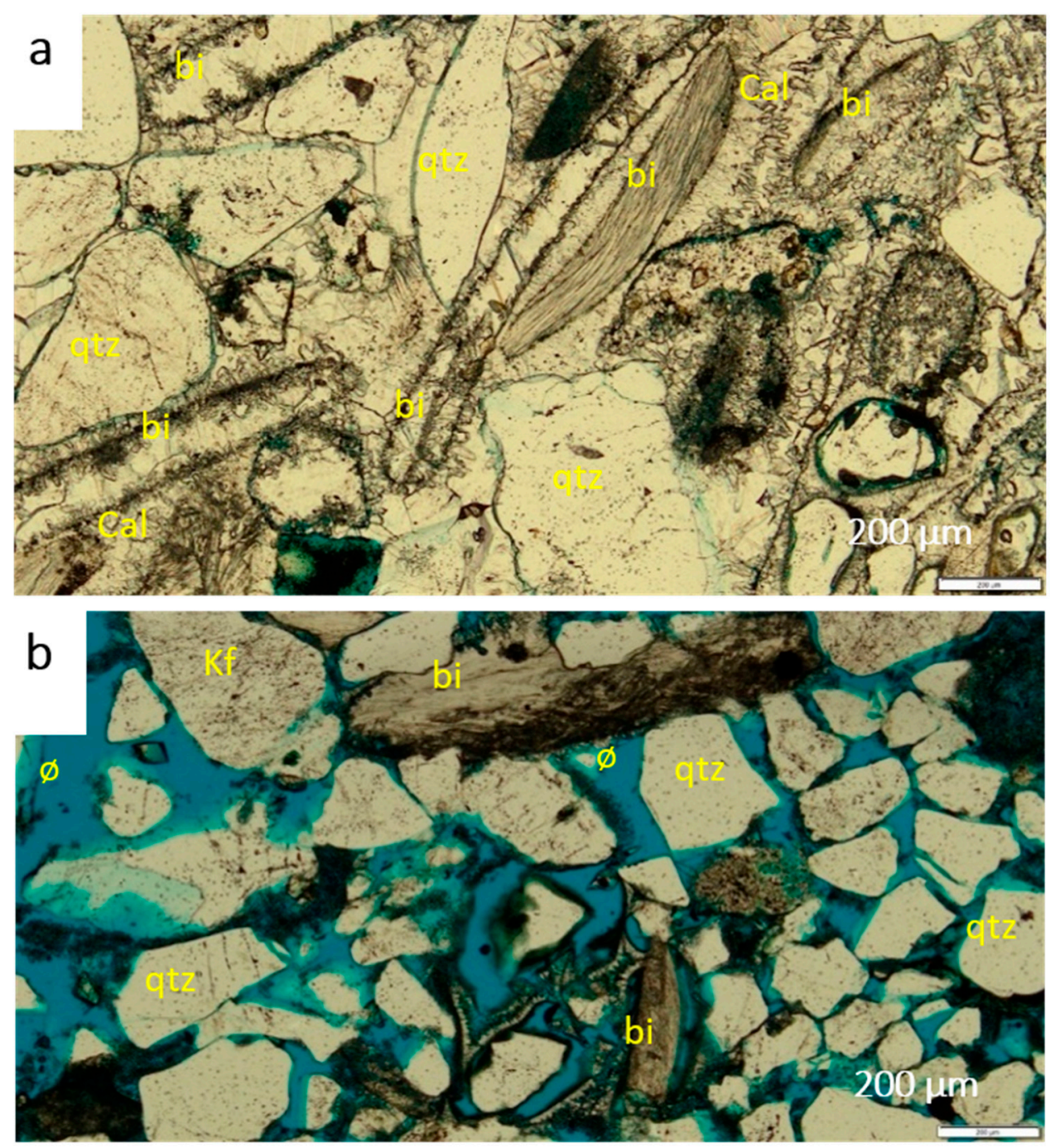

Figure 11. (a) PW7 (1130.0 m MD) light optics showing intense neomorphism of bivalve shells to calcite. The bivalve shells are not distinguishable from calcite cement and are only identified by the micrite envelopes outlining them in the cement (b) PW7 (1125.9 m MD)-in contrast to (a) shows fewer bivalve shells with less neomorphism and less calcite cementation Calcite cement (Cal), quartz (qtz), K-feldspar (Kf), bivalve (bi), pore space (ø).

There is 13.3 to $54.6 \%$ monocrystalline quartz (average $36.1 \%$ ) and about 0.7 to $16.4 \%$ polycrystalline quartz (average $9.0 \%$ ) (Table A1). Quartz is texturally mature with subrounded to rounded grains (Figures 7-10). Quartz is most abundant in the proximal upper shoreface facies association but shows no clear relationship from the foreshore to the offshore facies associations (Figure 12k).

The feldspars are mainly K-feldspar, which comprises trace to $4.0 \%$ of the total rock with an average of $1.0 \%$. Plagioclase feldspar comprises trace to $1.7 \%$, with an average of $0.2 \%$ (Table A1). The feldspars occur in various stages of dissolution (Figures 7a, 9a,b and 10a) with dissolved grains resulting in secondary porosity. Both feldspar types increase in proportion from the foreshore to offshore depositional environment (Figure 12a,b) possibly suggesting primary depositional controls on their abundance. 

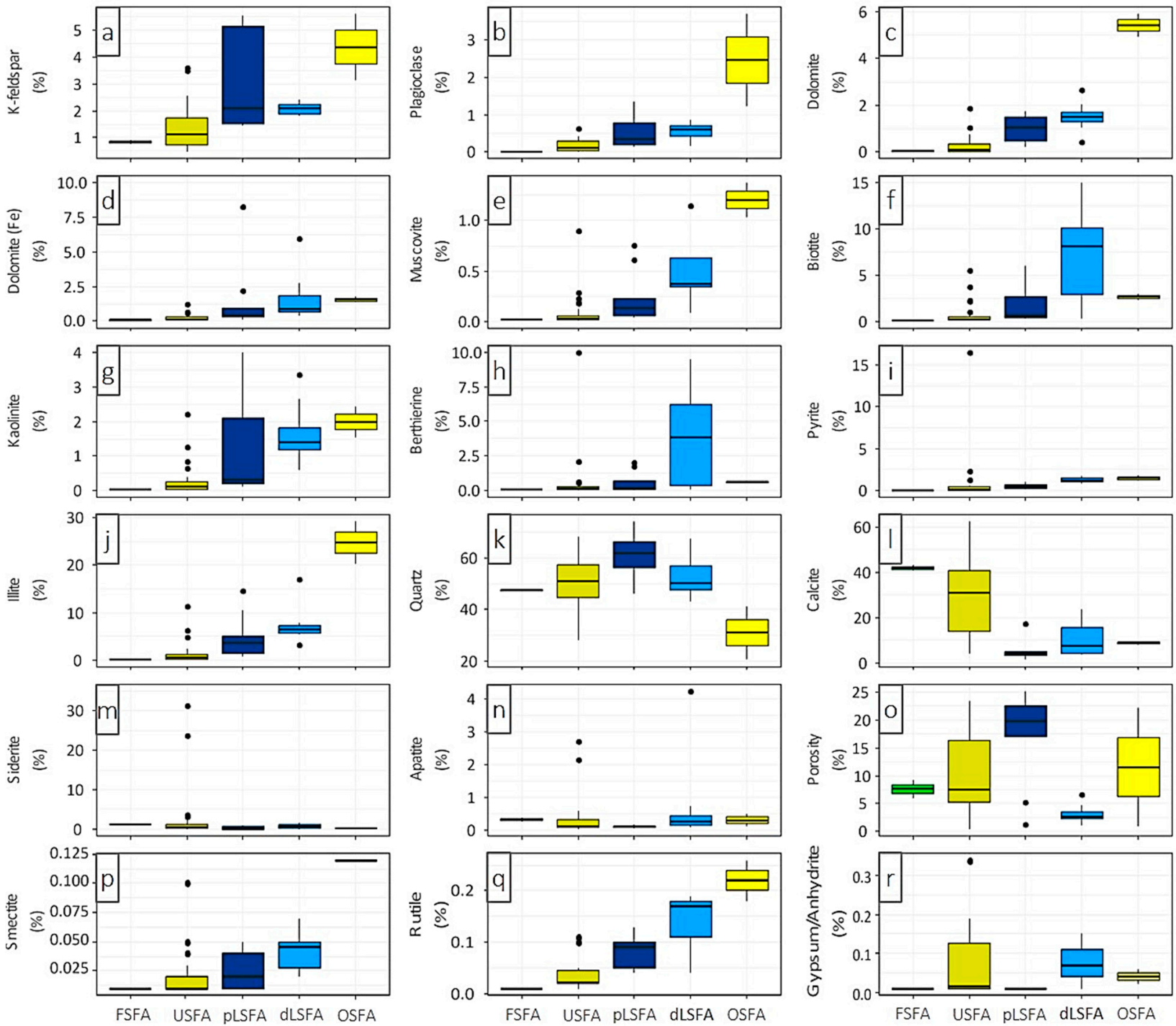

FSFA: Foreshore facies association; USFA: Upper shoreface facies association; pLSFA: Proxima lower shoreface facies association; dLSFA: Distal lower shoreface facies association; OSFA: offshore facies association

Figure 12. Boxplots relating SEM-EDS mineralogy to facies association. K-feldspar, plagioclase feldspar, dolomite, Fedolomite, muscovite, biotite, kaolinite, berthierine, pyrite and illite (a-j) increase basinward. Quartz (k), siderite (m), apatite (n), porosity (o) and gypsum/anhydrite (r) do not show a clear relationship with facies association. Smectite (p) and rutile (q) show an increase basinward from foreshore to offshore facies association. In contrast, calcite (l) shows a decrease basinward.

Lithic grains in these sandstones are composed of extrabasinal mudstones, quartzite, sandstone and chert. In the QFL analysis, bioclasts, Fe-ooids and muscovite are considered as lithic grains and have here been added to the lithics (Figure 6). Bioclasts are dominated by bivalves with minor echinoids, foraminifera and ostracods; bioclasts collectively represent about 0 to $4.0 \%$ with an average of $0.8 \%$. Fe-ooids, described later, make up between about 0 to $2.7 \%$ with an average of $0.12 \%$. Trace amounts of chlorite are present in the Corallian sandstones (Figure 13); however, it is not certain if chlorite is authigenic or detrital as chlorite is not evident as a cement or pore filling phase in optical petrographic analyses. 


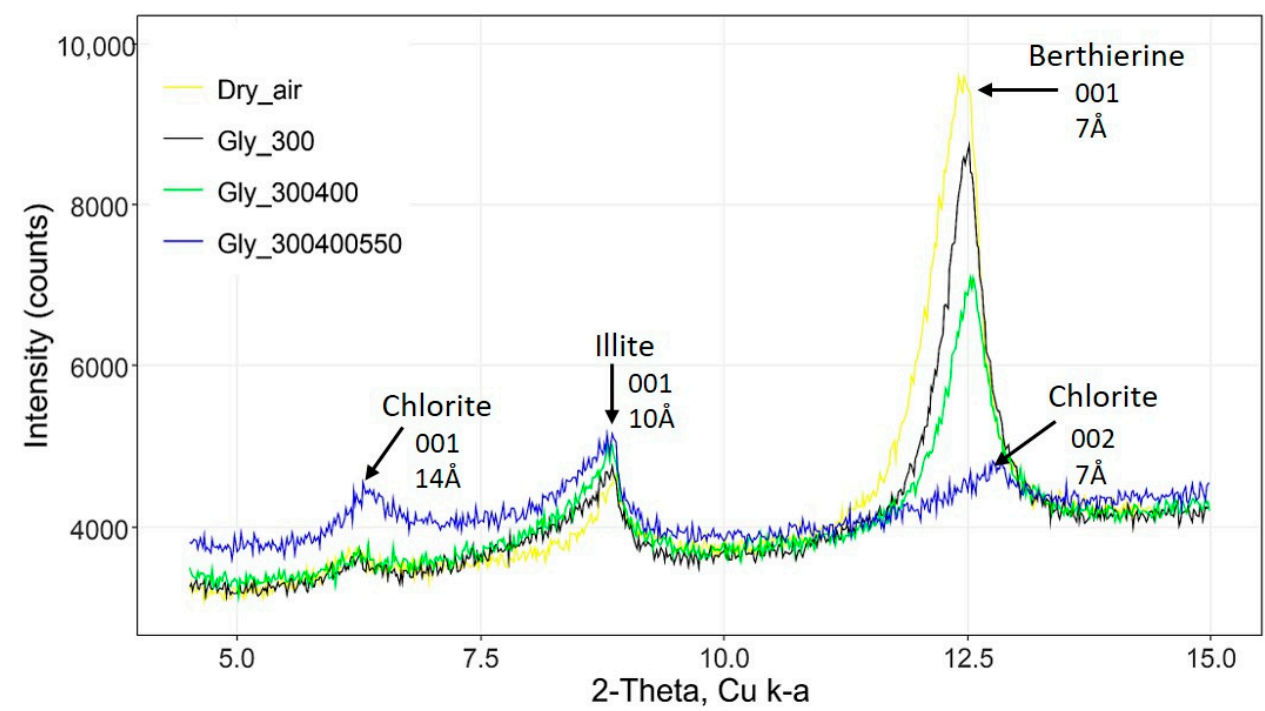

Figure 13. Various XRD traces from an Fe-rich clay-bearing samples from BL5 (2200.9 m MD) following various pre-analysis treatments: air-drying, glycolation followed by heating to $300{ }^{\circ} \mathrm{C}, 400{ }^{\circ} \mathrm{C}$ and $550{ }^{\circ} \mathrm{C}$ to investigate Fe-clay types. The $\mathrm{X}$-ray peaks show mineralogy with the separation showing reduction in peak intensity for Fe-clay, diagnostic of berthierine.

Fe-ooids have brown to olive-green cortices surrounding a nucleus composed of either quartz or heavy minerals (Figure 7c). Optical microscopy and SEM-EDS images reveal the presence of Fe-rich clay; XRD analysis confirmed the presence of berthierine (Figure 13).

Fe-ooids have a floating grain fabric where they are separated from other grains by pores or cement; cement growth locally truncates their grain boundaries, proving their detrital origin (Figures 7c, 9a and 10c). Fe-ooids increase in quantity from the foreshore to the proximal lower shoreface but there are none in the lower shoreface and offshore (Figure 14f).

Bioclasts are dominated by bivalves (Figures $7 \mathrm{~b}, 8 \mathrm{a}$ and 11a) and show evidence of intense bioerosion by micritisation (Figure 11a). Bioclast concentration is highest in the upper shoreface facies association and is lowest in the offshore facies association (Figure 14b); the variable degree of bioclast neomorphism makes interpretation of point count abundance difficult. If all calcite was derived from bioclasts, then total calcite from SEM-EDS analysis may be used as a proxy for total initial quantity of bioclasts; in this case offshore sediment had the lowest quantity of bioclasts (Figure 121).

The mineralogy of fine-grained sediment was resolved using SEM-EDS data (Figures $8 \mathrm{~d}$ and $9 \mathrm{c}$ ). Fine-grained sediments are mostly composed of illite, kaolinite, muscovite, biotite, minor quantities of pyrite, quartz, K-feldspar and plagioclase, as well as trace quantities of smectite (Figures 7d and 9b,c). SEM-EDS data show that biotite (Figure 12f), muscovite (Figure 12e), kaolinite (Figure 12g), pyrite (Figure 12i), illite (Figure 12j), and smectite (Figure 12p) all increase in proportion from foreshore to offshore environments.

Heavy minerals are dominated by apatite, which makes up about 0 to $1.0 \%$ (average $0.1 \%$ ) of total rock volume. Other heavy minerals include zircon, rutile and iron oxide, which occur in minor quantities $(<1 \%)$. Apatite occurs as fine grains visible in SEM-EDS (Figure 10b,c) and does not show a relationship with facies associations (Figure 12n). 

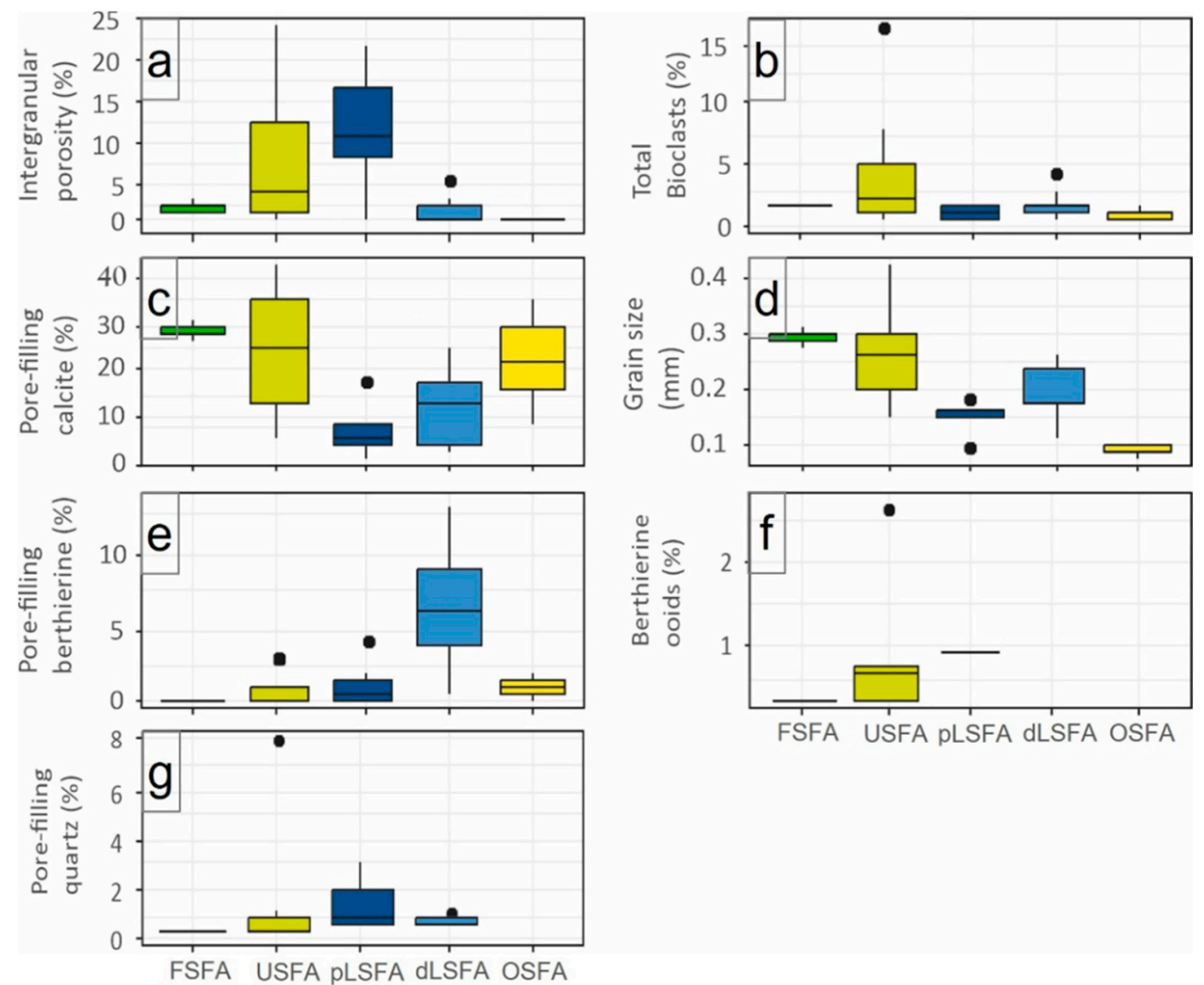

FSFA: Foreshore facies association; USFA: Upper shoreface facies association; pLSFA: Proxima lower shoreface facies association; dLSFA: Distal lower shoreface facies association; OSFA: offshore facies association

Figure 14. Boxplots relating point count data to facies associations: (a) intergranular porosity, (b) bioclasts, (c) pore-filling calcite, (d) grain size, (e) pore-filling berthierine, (f) Fe-ooids, and (g) pore-filling quartz. Intergranular porosity and pore-filling calcite show an inverse relationship while bioclasts and grain size show a good relationship with both reducing basinward from foreshore to offshore facies association. Pore-filling berthierine show an increasing trend from the foreshore to the proximal lower shoreface (e) similar to Fe-ooids (f) suggesting a genetic relationship. However, the absence of Fe-ooids in the distal lower shoreface and offshore facies association suggests other sources of authigenic berthierine apart from reprecipitation of Fe-ooids.

\subsubsection{Diagenetic Minerals and Cements}

The most common cements in these Corallian sandstones are, in order of abundance, calcite (Figures $7 \mathrm{~b}, \mathrm{c}, 12 \mathrm{l}$ and $14 \mathrm{c}$ ), illite (Figures $7 \mathrm{c}$ and 10d), siderite (Figures $7 \mathrm{a}$ and 12m), berthierine (Figures $7 \mathrm{~d}$ and 14e), pyrite (Figure 7c,d), dolomite (Figure 12c), Fe-dolomite (Figure 12d), quartz (Figures 10c, d and 14g), kaolinite (Figures 7b,d and 10c), and apatite (Figure 9a).

Calcite cement occurs as acicular and isopachous cements lining bivalve shells (Figure 7b) and poikilotopic crystals (Figure 11a) that fill pore spaces. Calcite represents the dominant cement by volume in the Corallian sandstones, locally constituting more than $40 \%$ of rock volume (Figure 14c). Pore-filling calcite constitutes about $1.6 \%$ in high porosity samples and up to $42.0 \%$ in samples with the lowest porosity (Table A1). A significant proportion, up to $23.7 \%$, of calcite cement is replacive (Figure 10b) (Table A1). Some calcite cement shows evidence of neomorphism of bivalve shells (Figure 11a), identifiable by the presence of earlier micrite envelopes.

Dolomite occurs as rhombic crystals (Figures 7a and 10a). Dolomite occurs in samples with evidence of calcite cement and grain dissolution (Figures 7a, 9a and 10a,b,d) and is also 
common in proximity to iron-rich minerals, e.g., siderite (Figure 9b). SEM-EDS analysis shows that non-ferroan dolomite constitutes up to $6 \%$, with an average of $0.7 \%$, while ferroan dolomite constitutes up to $13 \%$, with an average of $1.0 \%$ (Figure 12c,d, respectively).

Siderite occurs as yellow-brown rhombohedra under plain polarised light (Figure 7a). Siderite is heterogeneously distributed. It is pervasive in areas with calcite cement (Figure 7a) and occurs filling moldic pores from detrital grain dissolution (Figures $7 \mathrm{a}$ and 10b). Siderite is present up to $4.3 \%$ as pore-filling siderite, with an average value of $1.9 \%$ (Table A1). Grain replacive siderite locally constitutes up to $15.4 \%$ with a mean value of $0.49 \%$ (Table A1).

Berthierine occurs as pore-filling (Figure 9a), grain replacive (Figure 7b,d) and grain coating cement (Figure 10c). Berthierine grain coats form discontinuous rims around detrital grains and range from trace to $2.6 \%$ with an average of $0.2 \%$ of total rock volume (Table A1). Grain-coating berthierine has locally inhibited the growth of quartz cement (Figure 10c). Pore-filling berthierine occurs next to iron-rich minerals, for example, in Figure $7 d$, berthierine occurs adjacent to biotite-rich matrix and pyrite cement. Partly dissolved Fe-ooids, with their initial concentric laminae, contain replacive structureless berthierine (Figures 7a and 9a). Berthierine (Figure 12h) and biotite (Figure 12f) show an increase from foreshore to the distal lower shoreface, where they have the highest quantity, and then a reduction in quantity in the offshore, suggesting a genetic relationship between biotite and berthierine.

Illite is present as a porous, fiber-like mass of irregular crystals that fill pore spaces (Figure 10d). Rare grain-replacive illite is present (Figure 7c) where illite has grown in place of detrital muscovite. Pore-filling illite has an average of $2.7 \%$; replacive illite represents an average of $0.2 \%$ (Table A1).

Pyrite occurs in three main forms. Pore-filling pyrite surrounds detrital quartz and other grains (Figure 7d) and has equant outlines where it has grown into open pores (Figure 7d). Aggregates of framboidal pyrite (Figure 10d), and bioclast-replacive pyrite (Figure $7 \mathrm{~b}$ ) are also present in these sandstones. Pore-filling pyrite represents an average of $1.3 \%$ of total rock volume with a range between trace to a maximum of $14.8 \%$ of total rock volume (Table A1).

Apatite seems to be present as a cement as well as a detrital grain as it occurs as an unusual grain-coating phase (Figure 9a) but it only represents $0.1 \%$ of the sandstones, on average.

Incipient syntaxial quartz overgrowths have formed relatively early as they are surrounded by calcite cement (Figure 10d). Quartz cement is present as small (11 to $20 \mu \mathrm{m})$ euhedral outgrowths on detrital quartz grains (Figure 10c). Fluid inclusions seem to be absent in the quartz cements (Figure 7c,d). Authigenic quartz ranges from trace quantities to $7.9 \%$ with an average of $0.6 \%$ (Table A1). Quartz cement does not have rounded edges suggesting that it is not recycled from a previously deeply buried sandstone; quartz cement has grown in situ. For example, Figure $7 \mathrm{~b}$ displays perfectly euhedral multiple quartz outgrowths on a single grain that would not have survived weathering, erosion, transport, and deposition. Locally, quartz cement growth seems to have been inhibited by berthierine grain coats (Figure 10c). Quartz cement is more common in the cleaner, higher porosity sandstones that have less calcite cement (Figures 7c,d and 10d). Quartz cement increases from the foreshore facies association to the proximal lower shoreface facies association (Figure 14g).

Kaolinite occurs in the Corallian sandstones as discrete booklets and is visible where calcite cement is absent (Figures $7 \mathrm{~b}, \mathrm{~d}$ and 10c). Pore-filling kaolinite ranges from trace to $3.3 \%$ (Figure 10c); replacive kaolinite (typically after K-feldspar) ranges from trace to $1.3 \%$ (Figure 7d), (Table A1).

\subsubsection{Modal Porosity}

Point count porosity ranges from trace to $28.2 \%$. The main porosity type is intergranular porosity, which constitutes up to $23.0 \%$ of total rock volume, followed by moldic porosity 
which makes up to about $14.0 \%$ of total rock volume. Intergranular porosity tends to be lowest in samples with the greatest quantity of authigenic cements (Figure 11a). Moldic porosity occurs due to the dissolution of detrital grains such as Fe-ooids (Figure 7a,b) and feldspars (Figures 7a and 9b). Other porosity types include cement dissolution porosity (Figure 7d), intercrystalline porosity (Figure 10b), matrix porosity (Figure 7c) and fracture porosity (Figure 9d).

\subsection{Burial and Thermal History Modelling}

Burial curves show that the base of the Corallian sandstones (which is also the top of the Ampthill Clay Formation) was buried to a maximum depth of $\sim 1700 \mathrm{~m}$ TVD before uplift to the present depth of $~ 840$ m TVD.

Compactional porosity-loss was modelled as a function of depth and clay fraction following Ramm, Forsberg [38] with core analysis porosity data added from BL5, PW3 and PW7 (Figure 15b). The core porosity values were also projected to maximum burial, as modelled in Figure 15a. At the current depths, porosity is low compared to the modelled compaction curves (Figure 15b). If we assume that the sandstones had approximately $20 \%$ clay, then the best reservoir quality sandstones accord to rocks buried approximately $1000 \mathrm{~m}$ deeper than they are at the present time, if we assume that compaction was the dominant porosity-loss mechanism in the best reservoir quality sandstones. However, most of the core porosity cannot be accounted for by compactional processes, alone, implying that cement growth had a major impact on porosity. Overall, Figure 15b suggests that the porosity values at current depths are not just the result of compactional porosity-loss at maximum burial.
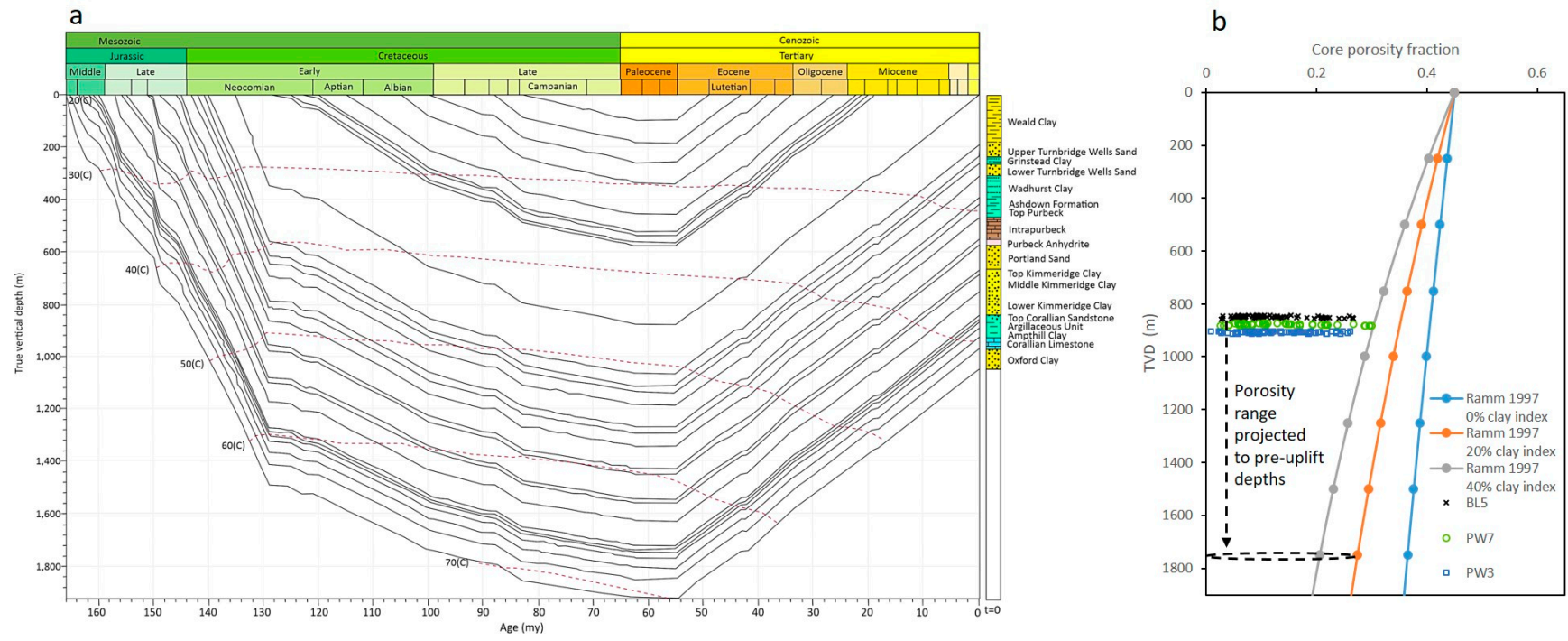

Figure 15. (a) Burial curve for the Weald area around Bletchingley-5 showing burial to the base of well BL5 in the Oxford Clay up to $\sim 1920 \mathrm{~m}$. The curve also shows uplift from 55 Ma to current depths. (b) Shows modelled compactional po-rosity-loss curves at different clay content after Ramm [38] and core porosity fractions from BL5, PW7 and PW3. Porosity loss in the Corallian sandstones did not follow the expected trend for mechanical compaction.

The burial model (Figure 15a) shows that the Corallian sandstones underwent initially rapid burial and heating and reached $60{ }^{\circ} \mathrm{C}$ at $124 \mathrm{Ma}$ (when at $1310.0 \mathrm{~m}$ TVD). The rate of burial and heating then slowed and they reached a maximum depth of about $1700 \mathrm{~m}$ and a temperature of about $66^{\circ} \mathrm{C}$ between $65 \mathrm{Ma}$ to $55 \mathrm{Ma}$. Subsequently, uplift led to the Corallian sandstones being cooled to the present-day depth of 800 to $900 \mathrm{~m}$ TVD and a temperature of between 35 and $40{ }^{\circ} \mathrm{C}$. The burial and thermal model (Figure 15a) seems to be supported by the analysis of porosity and compactional porosity-loss (Figure 15b). 
There are two possible petroleum source rocks in the modelled section: the Oxford Clay and the Kimmeridge Clay Formations. The top of the Oxford Clay Formation was buried to $\sim 1859 \mathrm{~m}$ TVD (Figure 15a). The younger Kimmeridge Clay Formation was buried to $\sim 1707 \mathrm{~m}$ TVD (Figure 15a). In this well, neither source rock reached thermal maturity sufficient for oil generation but note that the deeper (and thus hotter) Lower Jurassic Liassic source rock was not included in the model as it was not penetrated by the well.

\section{Discussion}

\subsection{Timing of Diagenetic Events}

Diagenesis in the Corallian sandstones occurred only in the eogenetic realm as the Corallian sandstones have only reached about $60^{\circ} \mathrm{C}$ (Figures 15 and 16) with the boundary between eo- and meso-diagenesis defined as being about 60 to $70^{\circ} \mathrm{C}$ [5]. The timing of diagenetic events is summarised in Figure 16. We interpret the first event to be feldspar dissolution (Figure 7a,b) which may have begun during weathering and sediment transport as well as continuing after burial $[39,40]$. Shell bioerosion (Figure $7 \mathrm{~b}$ ) is interpreted to have occurred early, under open marine photic conditions which are needed for the vital activities of microscopic boring algae [41,42]. Locally intense bioturbation (Figure 3e) occurred soon after burial, when animals were either seeking shelter or food [28]; it is likely that bioturbation led to any remaining organic matter associated with the bioclasts being destroyed. The initial stages of compaction seems to have occurred next (Figures $7 \mathrm{~b}$ and 10a). There was locally abundant growth of framboidal pyrite soon after deposition (Figure 10f) that also probably occurred during the initial stages of burial [43]. Framboidal pyrite was followed by the development of apatite, berthierine and calcite cement. Apatite occurs as a relatively unusual grain-coating phase (Figure 9a). Berthierine occurs as a grain-coating and pore-filling cement phase (Figure 10c,d). Poikilitopic calcite (calcite-2; Figures 7b and 11a) overlies an earlier generation of acicular calcite cement (calcite-1; Figure 7b); the latter possibly formed on or near the sediment surface. Poikilotopic calcite, the most important of all the pore-filling cements in the Corallian sandstones, locally filled most pore spaces with intergranular volumes of up to about $43 \%$, confirming that such cement formed before significant compaction had occurred [44].

Subsequent diagenetic processes included quartz overgrowth formation (Figures $7 \mathrm{~d}$, $8 \mathrm{~b}$ and 10a,c). Partial dissolution of Fe-ooids (Figures 8a and 10c) and feldspars (Figure 7a) occurred, possibly after quartz growth as quartz was preceded by berthierine coat formation (Figure 10c). Quartz growth and Fe-ooid dissolution were followed by hydrocarbon charge as shown by the presence of bitumen staining on quartz cement (Figure 7d) and on the internal dissolution surfaces of ooids (Figure $7 \mathrm{~b}$ ).

These events were followed by minor quantities of siderite and dolomite cement, replacive calcite (labelled calcite-3), and illite and kaolinite. The timing of siderite and dolomite cannot be differentiated (Figure 10b) but they occurred after Fe-ooid dissolution (Figure 10b). Replacive calcite-3 developed after siderite and dolomite (Figure 10b) but at about the same time as pore-filling illite (Figure 10d). Kaolinite seems to have been a late-stage diagenetic mineral that grew at the expense of detrital feldspars (Figure 10c).

Compaction occurred during burial, but these sandstones are typically cementationdominated rather than compaction-dominated (Figure 17); this was caused by the extensive development of locally-dominant poikilotopic calcite (Figure 11a) and other pore-filling minerals (Figure 7a). The least calcite-cemented sandstones display long grain to grain contacts evidencing the occurrence of compaction (Figure 7d). 


\begin{tabular}{|c|c|}
\hline Mineral & Very near surface \\
\hline Feldspar dissolution & $? \square$ Figures $7 \mathrm{a}, 9 \mathrm{a} \quad$ Figures $7 \mathrm{~d}, 10 \mathrm{a}$ \\
\hline Shell dissolution and degradation & Figure $11 \mathrm{a}$ \\
\hline Compaction & Figure 10a $\square \square \square \square \square$ Figure $7 \mathrm{~d}$ \\
\hline Pyrite & Figures $7 c, 10 f \square \square \square \square \square \square \square=? \quad$ Figure 9d \\
\hline Apatite & Figure $9 a$ \\
\hline Berthierine pore-filling/coats & Figures $10 c, 10 d$ \\
\hline Calcite cementation & Figures $7 b, 7 c, 8 a, 11 a \quad$ Figure $10 b$ \\
\hline Authigenic quartz & Figures $7 \mathrm{~d}, 8 \mathrm{~b}, 10 \mathrm{c}, 10 \mathrm{a}$ \\
\hline Hydrocarbon charge/Decarboxylation & Figure $7 \mathrm{c} \square \square \square \square \square \square \square$ \\
\hline Calcite cement dissolution & Figure $7 d$ \\
\hline Berthierine ooids dissolution & Figures $8 a, 10 c$ \\
\hline Siderite & Figures $8 a, 10 b$ \\
\hline Dolomite & Figures $10 a, 10 b, 10 d$ \\
\hline Illite & Figure 10d \\
\hline Kaolinite & Figures $7 d, 8 b, 10 c$ \\
\hline
\end{tabular}

Figure 16. Paragenetic sequence for the Corallian sandstones showing the sequence of diagenetic events. The sequence shows eogenetic events as the rocks have not been buried to more than about $1722 \mathrm{~m}$ and not exceeded about $60{ }^{\circ} \mathrm{C}$ (Figure 15a). The source of the evidence behind each interpreted step in the paragenetic sequence is listed in the figure. Evidence for the paragenetic sequence include K-feldspar dissolution (Figures 7a,d, 9a and 10a), shell dissolution and shell degradation (Figures $7 b$ and 11a), compaction (Figure 10a), pyrite (Figures 7b, 8d and 10f), apatite (Figure 9a), berthierine pore-filling/coats (Figures 9a and 10c), calcite cementation (Figure 7b,c, Figures 8a and 11a), quartz overgrowth (Figure 10c,d), hydrocarbon charge (Figure 7d), calcite dissolution (Figure 7d), Fe-ooids dissolution Figures 8a and 10c), siderite (Figures 8a and 10b), dolomite (Figure 10a,b,d), illite (Figure 10d), kaolinite (Figures 7d, 8b and 10c).

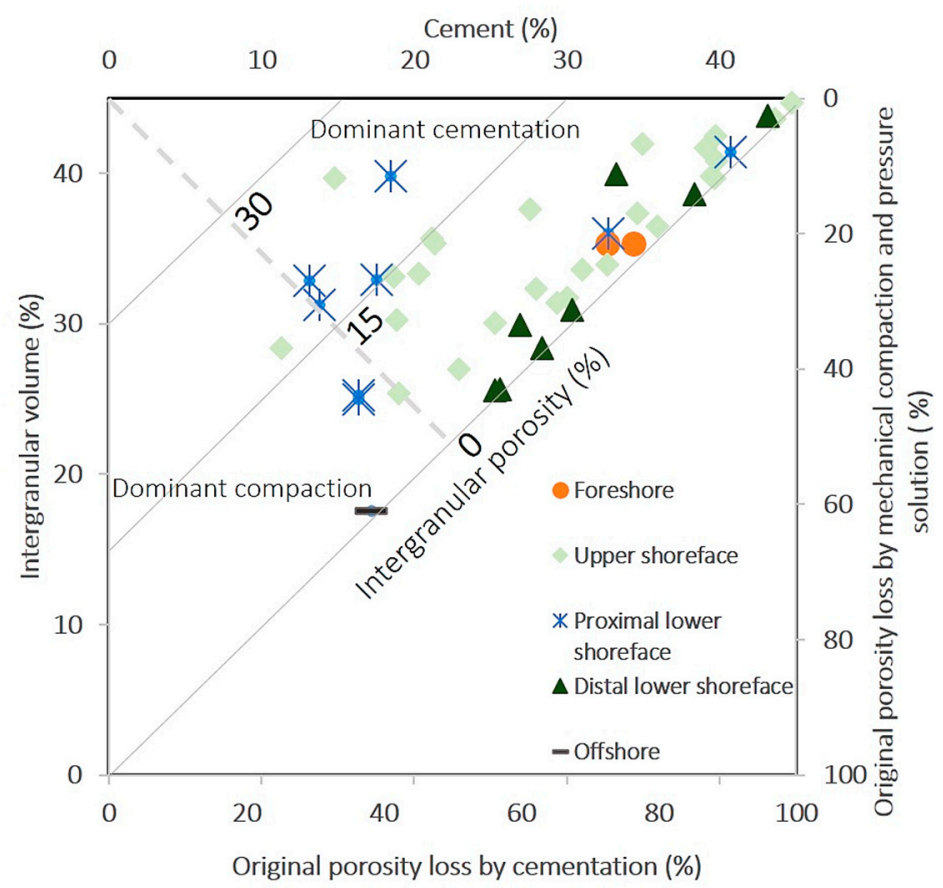

Figure 17. Intergranular volume (\%) versus cement (\%) diagram after the method developed by Houseknecht [45] showing the role of cementation and compaction in initial porosity-loss with the distal lower shoreface and offshore facies associations having the highest initial porosity-loss. 
The dissolution of calcite cement (Figure 7d), Fe-ooids (Figures $7 \mathrm{~b}$ and $8 \mathrm{a}$ ) and feldspars (Figure 7a,d), towards the end of the succession of events, led to the creation of secondary porosity. Based on XRD data, chlorite is present in trace quantities (Figure 13) but it is not apparent in optical images so we could not determine if it had detrital or authigenic origins. Chlorite is not present in sufficient quantity to influence reservoir quality or to ascertain its diagenetic relationships.

\subsection{Sources of Mineral Cements}

\subsubsection{Pyrite}

Pyrite formed early and precipitated throughout burial in the Corallian sandstones (Figures 8d and 10f). In addition, pyrite partly replaced bioclasts (Figure 7b) suggesting early sulfide mineral formation, before neomorphism of bivalves to calcite cement. Pyrite-filled pores (Figure 10d) formed adjacent to detrital grains and completely occluded pore spaces suggests that early diagenetic growth continued during subsequent burial. Framboidal pyrite is characteristic of early diagenesis while the coarser morphologies of pyrite, e.g., Figure 8d, typically represent later diagenesis [1,43]. Pyrite in marine sediments requires organic-rich, anoxic, reducing conditions to convert marine aqueous sulphate to sulfide and ferric iron to ferrous iron $[43,46]$. The iron in pyrite in the Corallian sandstones may have been supplied by depositional biotite, Fe-ooids, and detrital or seabed-related glauconite (Figure $8 b, d$ ). The Corallian sandstones were deposited in sulphate-rich sea water and the decomposition of organic matter potentially consumed oxygen and reduced the redox potential (Eh) producing sulfide and ferrous iron [47]. In the absence of carbonates, sulfide and ferrous iron combine to form iron sulfide.

\subsubsection{Apatite}

Apatite requires a source for phosphorus; apart from heavy mineral deposits, apatite is commonly associated with sediments that experienced much biological activity. Detrital apatite may be derived from bone and teeth fragments [47-49]. Apatite can also be enriched in coprolites [47] and can occur at a trace concentration in bioclasts [47,50]. It is likely that much of the diagenetic apatite found in the Corallian sandstones is recrystallised detrital apatite derived from bone fragments [48].

\subsubsection{Berthierine}

Berthierine is here interpreted to have formed under reducing conditions during shallow burial [51-54]. Grain-coating and pore-filling berthierine developed after dissolution of Fe-ooids which suggests that Fe-ooids may have sourced diagenetic berthierine (Figures $8 \mathrm{a}$ and 10c).

Berthierine forms as a result of reduction of iron at low Eh conditions [51-53]; these conditions commonly occur in nutrient-rich coastal waters [55]. The presence of detrital Fe-rich biotite (Figure 9b) and Fe-ooids in these sediments (Figure 7c) indicates that the primary sediment was enriched in iron. The presence of diagenetic siderite (see later and Figure 9b) and pyrite (Figures $8 \mathrm{~d}$ and 10f), as well as berthierine, confirms that Fediagenesis was an important aspect of the evolution of these rocks. The specific dominant Fe-phase was influenced by the supply of sulfide and bicarbonate, both probably from organic sources $[49,56]$. Berthierine grows in sulfide- and bicarbonate-limited pore waters, influenced by a suite of bacterial processes [57]. The degradation of Fe-ooids led to the formation of thin berthierine coats (Figure 10) and pore-filling berthierine (Figure 7a) similar to berthierine in the Wealden sandstones of the Paris Basin [58].

Another possible source of berthierine is detrital biotite (Figure 7d). Authigenic berthierine tends to be physically close to detrital biotite-rich matrix (Figures 8d and 9a). There is a significant correspondence between biotite and berthierine enrichment patterns as a function of facies association (Figure 12f,h). Biotite can be a source of the main ingredients for berthierine; however, the latter has a higher $\mathrm{Al} / \mathrm{Si}$ ratio than the former suggesting either that (i) silica was exported to other parts of the Corallian sandstone (e.g., 
as quartz cement) or (ii) Al was imported from other parts of the Corallian sandstone (e.g., from alumino-silicate mineral breakdown).

\subsubsection{Calcite}

Early calcite cement is here interpreted to have formed from neomorphism of bivalve tests, starting soon after deposition and continuing during burial. Petrographic evidence shows bivalve shells with various degrees of neomorphism (Figures 7b, 8a and 11a) to calcite $[42,59,60]$. Neomorphism of aragonitic bivalve shells is emphasised in Figure 11a where pervasive calcite cement cannot be distinguished from bivalve shells except where micrite envelops outline the boundary of bivalve shells which neomorphosed into calcite. In contrast, Figure 11 b shows a porous rock, with unaltered bivalve shells and very little calcite cement as the shells have only been slightly micritised, with no significant neomorphism (Figure 11b), leading to a low calcite cement volume.

Calcite- 1 forms acicular rims on bivalve shells (Figures $7 \mathrm{~b}$ and $11 \mathrm{a}$ ) and does not significantly project into pore space, indicating early formation. Acicular rims are surrounded by poikilotopic calcite (calcite-2) which pervasively fills pore spaces indicating development of calcite as neomorphism progressed (Figure 11a).

Secondary calcite (calcite-3) is here interpreted to have formed after local dissolution of detrital or eogenetic calcite following addition of $\mathrm{CO}_{2}$-rich waters during burial, possibly by source rock decarboxylation. There is evidence for dissolution of calcite cement (Figure 7d), Fe-ooids (Figures 8a and 10c,e) and feldspars (Figures 7a,d and 9a,b). There is evidence of calcite development following grain dissolution (Figures 9a and 10b). The development of calcite-3 after dissolution is here interpreted to occur due to reduction in the partial pressure of $\mathrm{CO}_{2}\left(\mathrm{PCO}_{2}\right)$ during grain and cement dissolution causing a reduction in acidic conditions and a return to more neutral conditions suitable for calcite development.

\subsubsection{Quartz}

Typically, quartz cementation is a kinetically-driven process whose rate depends on a silica source, mass transfer to the site of cementation and, finally, cement precipitation [61]. Quartz cement requires a silica source, a mode of transport and a site for deposition or crystallisation; these depend on detrital mineralogy, temperature, grain size and degree of grain coat coverage [62]. Silica for quartz cementation is here interpreted to be sourced from feldspar dissolution (Figures 7a,d and 9a,b) $[39,63,64]$ as well as the alteration of other detrital alumino-silicates such as Fe-ooids (Figure 10c,e), degradation of biotite (Figure 9a) and muscovite (Figure $8 \mathrm{c}$ ).

The low temperature $\left(<60^{\circ} \mathrm{C}\right)$, shallow depth (Figure 15) of the quartz cement in the Corallian sandstones is significant as it shows that incipient quartz cementation occurs at shallow depths, similar to Lower Cretaceous Wealden sands in the Paris Basin [58]. This is noteworthy as it shows that quartz cement does not only develop at temperatures greater than $80{ }^{\circ} \mathrm{C}$ as has been widely reported in literature $[62,63,65,66]$. Furthermore, this low temperature quartz cement was locally inhibited by berthierine coats (Figure 10c). Inhibition of quartz cement is commonly linked to chlorite grain coats with berthierine serving as a possible precursor mineral for chlorite [55,57]. The inhibition of quartz overgrowth here proves that the preservation of reservoir quality by grain-coats starts during eodiagenesis with berthierine coats. Berthierine coats are therefore potentially important in shallow reservoirs where chlorite coats have not developed. As has been recently shown for shallow buried sandstones in NW France [58], berthierine coats can therefore preserve reservoir quality by inhibiting quartz cement at temperatures much lower than $70{ }^{\circ} \mathrm{C}$.

\subsubsection{Siderite}

The precipitation of siderite is interpreted to be a late-stage event, as seen in Figure 10b, where siderite precipitated in moldic pore. Siderite was probably derived from iron supplied by alumino-silicates (e.g., berthierine in Fe-ooids, Figure 7a, or biotite) and 
carbonates. This is similar to models of siderite origin published by Macquaker, Taylor [49], Gehring [67].

\subsubsection{Dolomite}

Dolomite is here interpreted to have developed following the dissolution of calcite cement and biotite or Fe-ooids. Dolomite rhombohedra locally occur close to dissolved Fe-ooids (Figures $8 \mathrm{a}$ and 10a,d). As magnesium and iron ions are present in berthierine [53], alteration of berthierine in ooids releases $\mathrm{Fe}^{2+}$ and $\mathrm{Mg}^{2+}$ to combine with carbonate ions to produce dolomite [52]. In addition, dolomite and Fe-dolomite show a similar pattern, by facies association, to biotite (Figure 12c,d,f) which suggests a genetic relationship where iron and magnesium released from biotite alteration can also combine with carbonate ions to produce dolomite.

\subsubsection{Illite}

Illite cement is here interpreted to develop from the alteration of phyllosilicate minerals such as muscovite (Figure 8c) and K-feldspar (Figure 10a) [68]. Illite is also interpreted to result from the dissolution of feldspars (Figure 7a) [59].

\subsubsection{Kaolinite}

Similar to illite, kaolinite is interpreted to have precipitated following alumino-silicate mineral breakdown, e.g., Emery, Myers [39], Orem and Finkelman [69]. Meteoric water flushing has widely been discussed as causing the growth of kaolinite in shallow sandstones [39,40], with the leaching of feldspars and mica occurring at depths as shallow as 10 to $20 \mathrm{~m}$ [70]. As kaolinite is mostly in pore spaces close to dissolved silicates (Figure 10c), it is interpreted to have formed as a result of dissolution of K-feldspar [59] (Figures $7 \mathrm{~d}$ and $9 \mathrm{a}, \mathrm{b}$ ) in iron-deficient acidic pore-fluids after $\mathrm{CO}_{2}$ flux, possibly from source rocks.

\subsection{Role of Compaction and Cementation on Porosity}

Detrital mineralogy in the Corallian sandstones is dominated by quartz (Figure 6). Quartz-rich sandstones undergo less compaction than ductile-rich sandstones [45,71]. As the modelled burial curves in Figure 15b illustrate, porosity-loss did not follow the expected trend for mechanical compaction. The deviation from the modelled trend suggests that mechanical compaction is not the dominant control on porosity evolution.

The degree of compactional and cementational porosity-loss was quantified using point count data using the approach described by Houseknecht [44] employing an assumed initial porosity of $45 \%$ (Figure 17). The Houseknecht plot shows that cementation is the dominant control on reservoir quality for the Corallian sandstones. All but three samples plot in the quadrant for porosity-loss being dominated by cementation. The three samples that lie in the field of dominant compactional porosity-loss either have a relatively low cement content (i.e., BL5-2209.46 m MD, cement content of 11.34\%; BL5-2208.0 m MD, cement content of $16.35 \%$; BL5-2211.6 m MD, cement content of $16.36 \%$ ) or have a high matrix clay content (PW3-1098.3 m MD, 61\% clay).

\subsection{Controls on Diagenesis and Reservoir Quality}

The Corallian sandstones do not have a simple relationship between depositional facies and reservoir quality. For example, there is no clear relationship between reservoir quality and either grain size or sorting (Figure 18a). In addition, there is no apparent relationship between facies association and reservoir quality (Figure 18b). The best reservoir quality samples, i.e., those that plot in the top-right corner of Figure 18c, tend to have little calcite or clay minerals. The worst reservoir quality samples have high calcite and/or clay contents (Figure 18c). This shows that there is a strong diagenetic and cement-related control on reservoir quality. Samples with moderate to high porosity, low calcite but high clay content, have lower permeability, by up to an order of magnitude or more, than 
samples in their porosity range (Figures 5 and 18c). This indicates that permeability is strongly affected by clay mineral content, even in high porosity samples.

a

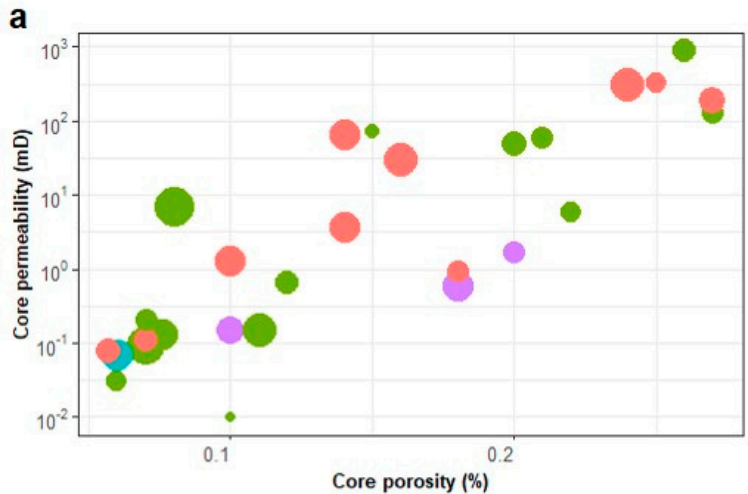

b

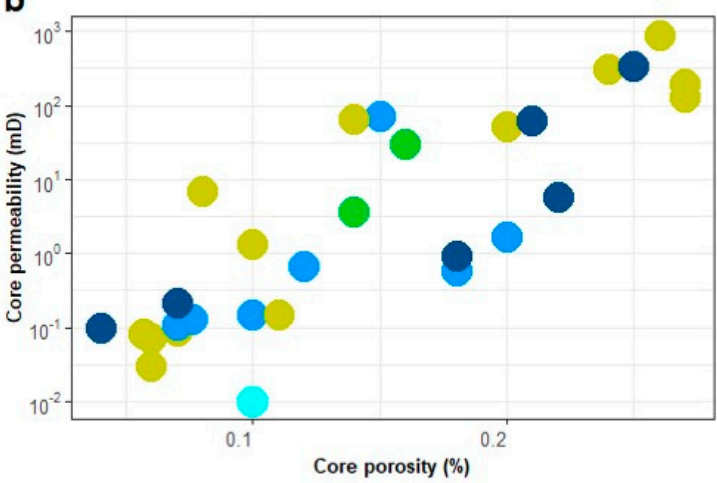

c

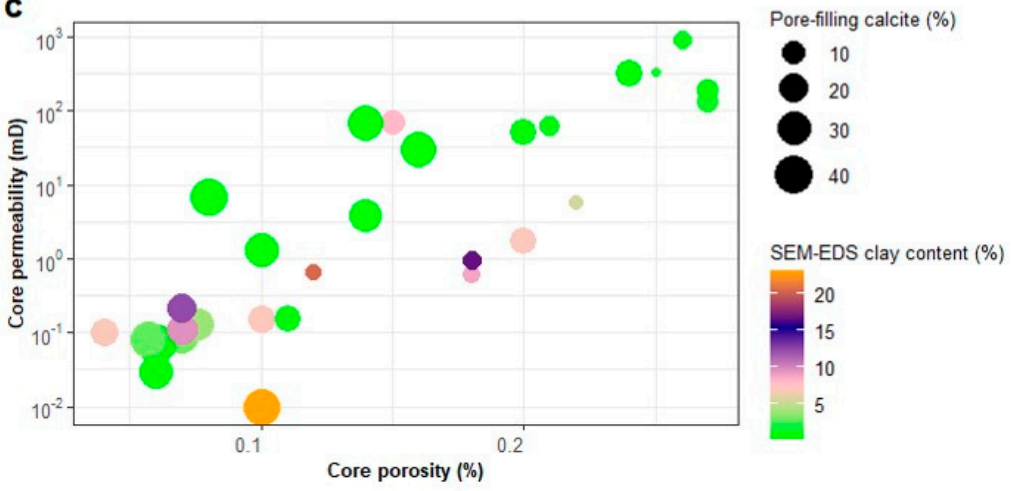

Grain size (mm)

- 0.1

0.2

0.3

0.4

Sorting (Trask)

- moderately well sorted

- moderately sorted

- well sorted

- poorly sorted
Facies association

- Foreshore

- Upper shoreface

- Proximal lower shoreface

- Distal lower shoreface

- Offshore

Figure 18. Assessment of the controls on core porosity and permeability for all three wells: (a) No clear pattern between grain size and sorting with porosity and permeability (b) No clear relationship between porosity and permeability with facies associations as the best reservoir quality is in the upper shoreface and proximal lower shoreface facies associations which also have samples with low porosity and permeability. (c) The best reservoir quality zones have low calcite content and clay content. Samples with low calcite content and high clay content have a lower permeability range than samples in their porosity range.

Reservoir quality was partly preserved by berthierine grain coats which inhibited the development of quartz cement (Figure 10c). Porosity was significantly enhanced by grain dissolution and the creation of secondary porosity (Figures $7 \mathrm{a}, \mathrm{b}, 8 \mathrm{a}$ and $10 \mathrm{c}, \mathrm{d}, \mathrm{e})$. However, reservoir quality was minimally affected by grain replacive cementation which filled secondary pores created by dissolved grains without enhancing or destroying porosity (Figure 10b). 


\subsection{Reservoir Quality Model}

A reservoir quality evolutionary path, showing the effects of calcite and clay minerals, is illustrated in Figure 19 illustrating the controls on reservoir quality using SEM-EDS images for selected points. The lines connecting the SEM-EDS images show the reservoir quality evolutionary path for various sandstone types. Pattern 1 shows the evolutionary path of clean sandstones and illustrates how an increase in overall clay mineral content and calcite destroyed reservoir quality. Pattern 2 shows the effect of dissolution of cements and grains on reservoir quality, whereby there is an increase of porosity and permeability. Pattern 2 has a higher permeability range than sediments on pattern 1, possibly because of extensive creation and connection of pores from dissolution at the current shallow depths without significant compensative pore size reduction from compaction. Pattern 3 shows how clays disproportionally decrease permeability in calcite-poor samples indicating that calcite-poor sandstones will not have high permeability if they are clay-rich.

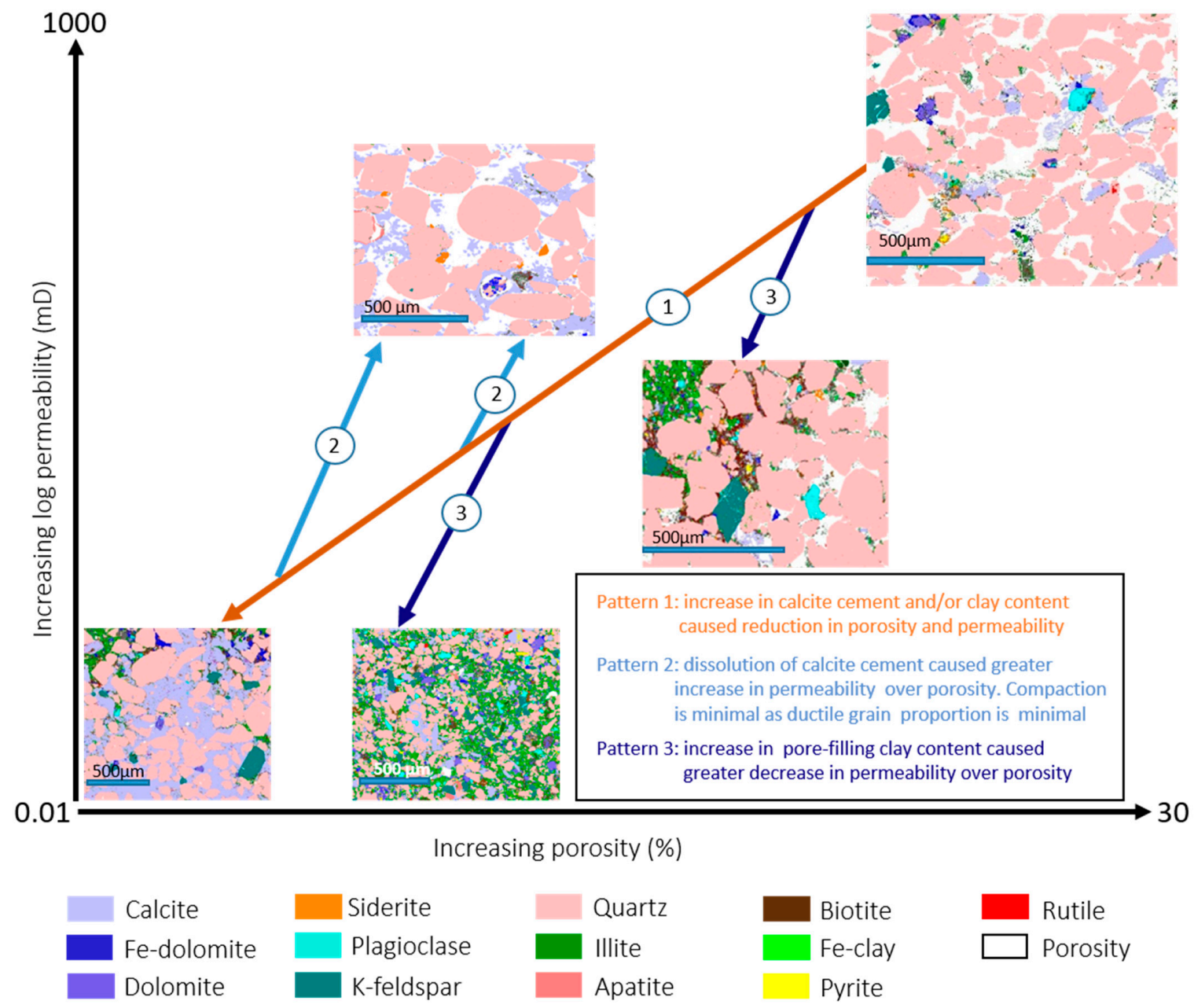

Figure 19. A model for reservoir quality evolution of the Corallian sandstones with SEM-EDS images of selected samples from points in Figure 18c. The arrows are a schematic for reservoir quality evolution patterns from a clean sand-rich. (1) Corallian sandstones to an argillaceous calcite cemented sandstone; (2) The effect of calcite cement dissolution and grain dissolution while; (3) The effects of clay under different porosity levels. The model emphasises the dominant influence of calcite cement on mechanical compaction, porosity and permeability loss as well as clay minerals in permeability reduction.

Corallian sandstones rich in bioclast-derived calcite presumably were deposited in shallow, limpid ocean waters with a great abundance of biological activity. The addition of a quartz-dominated sand to a site of active bioclast accumulation led to compromised reservoir quality in the subsurface due to the propensity for such bioclast-quartz sand 
hybrids to become calcite cemented [12,60,72]. Conversely, sandstones rich in matrix clay, presumably in turbid ocean waters, near to the site where rivers fed sediment into the ocean, have far fewer bioclasts and thus much less calcite cement [72]. However, these clay-rich Corallian sandstones have their subsurface reservoir quality strongly affected by the presence of the same clay minerals that inhibited bioclast development at the site of deposition.

\section{Conclusions}

1. Upper Jurassic Corallian sandstone reservoirs in the Weald Basin, UK, were buried to a maximum of about $1700 \mathrm{~m}$ and achieved a maximum temperature of about $60{ }^{\circ} \mathrm{C}$ before being uplifted to present depths of about 800 to $900 \mathrm{~m}$ and temperature of about $40{ }^{\circ} \mathrm{C}$.

2. The Corallian sandstones have moderate to poor reservoir quality. The diagenetic processes that modified these sandstones include the growth of various cements (in approximate order of abundance: calcite, siderite, dolomite, Fe-dolomite, quartz, pyrite, apatite, berthierine, kaolinite and illite) as well as minor compaction. Reservoir quality was also influenced by dissolution of Fe-ooids, K-feldspar, plagioclase feldspar and calcite cement.

3. Reservoir quality does not seem to have strong depositional controls. Corallian sandstones are cementation-dominated, as opposed to compaction-dominated, calcite is the dominant cement and the main control on reservoir quality. Calcite cement was derived from detrital bioclasts co-deposited with the sand grains.

4. Kaolinite and illite occur as pore-filling clays while berthierine occurs as pore-filling, grain replacive and grain coating clay.

5. Quartz cement has a low temperature, early diagenetic origin but is volumetrically minor, at least, in part, due to its inhibition by berthierine grain coats. Berthierine clay coats locally preserved reservoir quality by preventing quartz overgrowths.

6. Clay minerals (kaolinite and illite) locally reduced reservoir quality, especially decreasing permeability for only a small decrease in porosity.

7. Secondary porosity, following dissolution of calcite cement and detrital feldspars and Fe-ooids, locally increased porosity and permeability.

8. The best reservoir quality in Corallian sandstones is found in the cleanest, most clayfree sandstones with the least amount of calcite cement. Detrital bioclast content is the over-riding control on reservoir quality in these sandstones.

Author Contributions: Conceptualisation, D.V.B. and R.H.W.; core description, D.V.B.; methodology, D.V.B. and R.H.W.; validation, D.V.B. and R.H.W.; formal analysis, D.V.B. and R.H.W.; investigation, D.V.B. and R.H.W.; data curation, D.V.B. and R.H.W.; writing-original draft preparation, D.V.B.; writing-review and editing, D.V.B. and R.H.W.; supervision, R.H.W. All authors have read and agreed to the published version of the manuscript.

Funding: This research project was funded by the Petroleum Technology Development Fund (PTDF).

Acknowledgments: We wish to thank the British Geological Survey at Keyworth, Nottinghamshire, for access to the Palmers Wood and Bletchingley cores. We thank staff from IGas for providing log and core data as well as well reports. We are also grateful to the Petroleum Technology Development Fund (PTDF) for funding this research. Petrographic analysis was carried out at the Diagenesis Research Group at the University of Liverpool and portable X-ray fluorescence spectrometry was also provided by the Central Teaching Labs (CTL) of the University of Liverpool. The QEMSCAN used in this study was loaned to Liverpool's Diagenesis Research Group by the FEI courtesy of Alan Butcher. Basin modelling was undertaken using BasinMod software with the license gifted to the Diagenesis Research Group by Platte River Associates. Thanks to James Utley of the Diagenesis Research Group for his help with QEMSCAN analyses during the course of this study.

Conflicts of Interest: The authors declare no conflict of interest. The sponsors had no influence on the research topic, data collection, analyses and the conclusions of this study. 


\section{Appendix A}

Table A1. Point count data for the Corallian sandstones.

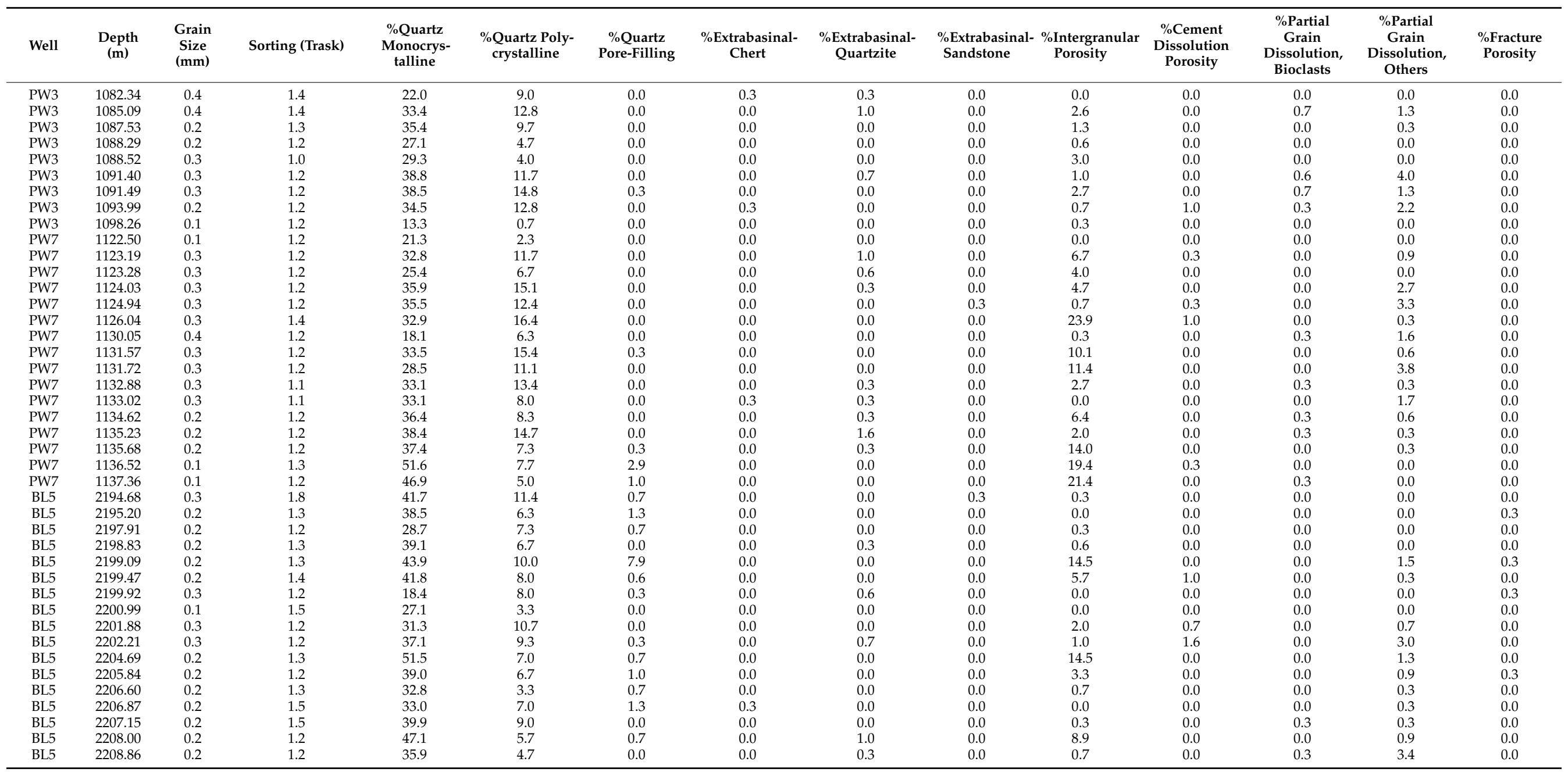


Table A1. Cont.

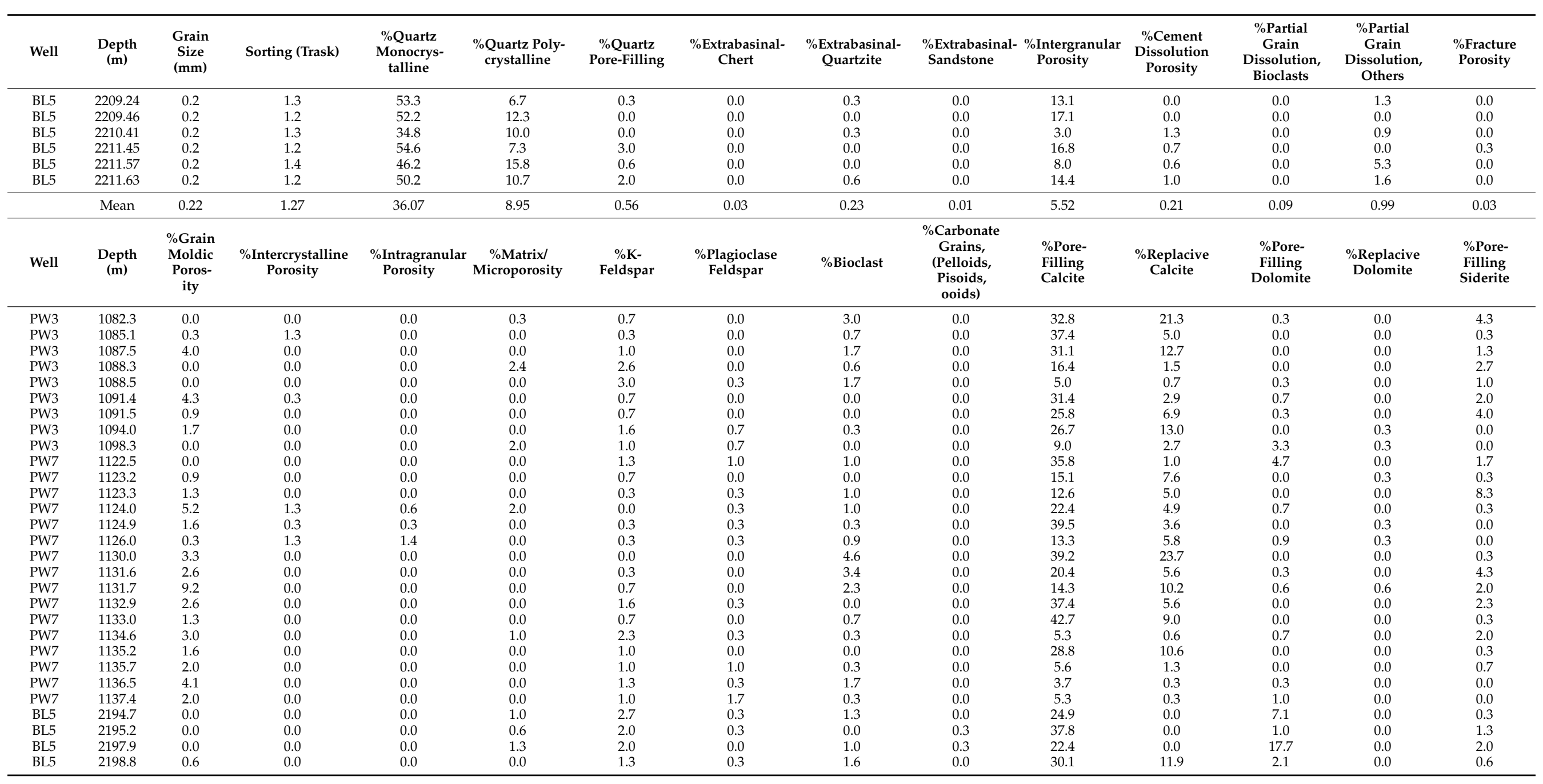


Table A1. Cont.

\begin{tabular}{|c|c|c|c|c|c|c|c|c|c|c|c|c|c|c|}
\hline Well & $\begin{array}{l}\text { Depth } \\
\text { (m) }\end{array}$ & $\begin{array}{l}\text { Grain } \\
\text { Size } \\
(\mathrm{mm})\end{array}$ & Sorting (Trask) & $\begin{array}{l}\text { \%Quartz } \\
\text { Monocrys- } \\
\text { talline }\end{array}$ & $\begin{array}{l}\text { \%Quartz Poly- } \\
\text { crystalline }\end{array}$ & $\begin{array}{c}\% \text { Quartz } \\
\text { Pore-Filling }\end{array}$ & $\begin{array}{c}\text { \%Extrabasinal- } \\
\text { Chert }\end{array}$ & $\begin{array}{l}\text { \%Extrabasinal- } \\
\text { Quartzite }\end{array}$ & $\begin{array}{l}\text { \%Extrabasinal- } \\
\text { Sandstone }\end{array}$ & $\begin{array}{l}\text { \%Intergranular } \\
\text { Porosity }\end{array}$ & $\begin{array}{c}\text { \%Cement } \\
\text { Dissolution } \\
\text { Porosity }\end{array}$ & $\begin{array}{c}\text { \%Partial } \\
\text { Grain } \\
\text { Dissolution, } \\
\text { Bioclasts }\end{array}$ & $\begin{array}{c}\text { \%Partial } \\
\text { Grain } \\
\text { Dissolution, } \\
\text { Others }\end{array}$ & $\begin{array}{c}\text { \%Fracture } \\
\text { Porosity }\end{array}$ \\
\hline BL5 & 2199.1 & 3.6 & 0.0 & 0.0 & 0.0 & 4.0 & 0.0 & 0.0 & 0.0 & 6.4 & 0.0 & 1.0 & 0.0 & 0.3 \\
\hline BL5 & 2199.5 & 1.0 & 0.0 & 0.0 & 1.0 & 1.0 & 0.0 & 0.3 & 0.0 & 14.3 & 0.3 & 2.3 & 0.0 & 0.7 \\
\hline BL5 & 2199.9 & 0.0 & 0.0 & 0.0 & 0.0 & 0.0 & 0.0 & 0.6 & 0.0 & 12.7 & 0.3 & 0.3 & 0.0 & 41.2 \\
\hline BL5 & 2201.0 & 0.0 & 0.0 & 0.0 & 0.3 & 0.7 & 0.0 & 0.6 & 0.0 & 12.0 & 0.3 & 2.3 & 0.0 & 1.0 \\
\hline BL5 & 2201.9 & 1.3 & 0.0 & 0.0 & 0.0 & 0.3 & 0.0 & 1.3 & 0.0 & 34.0 & 14.8 & 0.0 & 0.0 & 0.3 \\
\hline BL5 & 2202.2 & 1.6 & 0.0 & 0.0 & 0.0 & 0.0 & 0.0 & 0.3 & 0.0 & 28.4 & 10.9 & 1.0 & 0.3 & 1.0 \\
\hline BL5 & 2204.7 & 2.9 & 0.6 & 0.0 & 0.0 & 1.0 & 0.3 & 0.6 & 0.0 & 9.3 & 0.9 & 1.0 & 0.0 & 1.0 \\
\hline BL5 & 2205.8 & 1.3 & 0.0 & 0.0 & 2.0 & 2.0 & 0.0 & 0.7 & 0.0 & 6.3 & 0.0 & 0.7 & 0.0 & 0.7 \\
\hline BL5 & 2206.9 & 0.0 & 0.0 & 0.0 & 2.4 & 3.0 & 0.3 & 1.3 & 0.0 & 3.4 & 0.7 & 0.0 & 0.3 & 0.3 \\
\hline BL5 & 2207.1 & 0.0 & 0.0 & 0.0 & 1.0 & 1.0 & 0.3 & 2.3 & 0.0 & 4.6 & 1.0 & 2.0 & 0.0 & 0.0 \\
\hline BL5 & 2208.0 & 3.9 & 0.0 & 0.0 & 1.0 & 1.0 & 0.0 & 0.0 & 0.0 & 3.0 & 0.0 & 0.3 & 0.0 & 0.7 \\
\hline BL5 & 2208.9 & 0.6 & 0.0 & 0.0 & 0.3 & 0.7 & 0.0 & 0.6 & 0.3 & 37.8 & 8.2 & 0.3 & 0.6 & 0.7 \\
\hline BL5 & 2209.2 & 1.9 & 0.0 & 0.3 & 0.0 & 0.3 & 0.0 & 0.0 & 0.0 & 15.1 & 0.9 & 0.0 & 0.0 & 0.0 \\
\hline BL5 & 2209.5 & 3.6 & 0.0 & 0.0 & 0.3 & 0.6 & 0.0 & 1.3 & 0.0 & 8.3 & 0.9 & 0.7 & 0.0 & 0.0 \\
\hline BL5 & 2210.4 & 1.3 & 0.0 & 0.0 & 1.0 & 0.0 & 0.3 & 0.0 & 0.7 & 24.8 & 13.9 & 0.3 & 0.0 & 0.3 \\
\hline BL5 & 2211.4 & 3.6 & 0.0 & 0.0 & 0.3 & 0.7 & 0.0 & 0.9 & 0.0 & 1.6 & 0.3 & 1.3 & 0.0 & 0.3 \\
\hline BL5 & 2211.6 & 1.9 & 0.0 & 0.3 & 2.0 & 0.0 & 0.3 & 0.0 & 0.0 & 8.7 & 0.3 & 2.7 & 0.0 & 0.7 \\
\hline \multirow[t]{2}{*}{ BL5 } & 2211.6 & 2.3 & 0.0 & 0.0 & 0.7 & 0.3 & 0.3 & 0.3 & 0.0 & 7.3 & 0.0 & 0.3 & 0.0 & 0.0 \\
\hline & Mean & 1.75 & 0.11 & 0.06 & 0.51 & 1.08 & 0.22 & 0.85 & 0.04 & 19.37 & 4.82 & 1.39 & 0.07 & 1.95 \\
\hline Well & $\begin{array}{c}\text { Depth } \\
\text { (m) }\end{array}$ & $\begin{array}{l}\text { \%Replacive } \\
\text { Siderite }\end{array}$ & $\begin{array}{l}\text { \%Pore-Filling } \\
\text { Illite }\end{array}$ & $\begin{array}{l}\text { \%Replacive } \\
\text { Illite }\end{array}$ & \%Muscovite & \%Biotite & $\begin{array}{c}\text { \%Pore-Filling } \\
\text { Kaolinite }\end{array}$ & $\begin{array}{l}\text { \%Replacive } \\
\text { Kaolinite }\end{array}$ & $\begin{array}{l}\text { \%Berthierine } \\
\text { Replacive }\end{array}$ & $\begin{array}{l}\text { \%Berthierine } \\
\text { Ooids }\end{array}$ & $\begin{array}{c}\text { \%Berthierine } \\
\text { Replacing } \\
\text { Berthierine } \\
\text { Ooid }\end{array}$ & $\begin{array}{c}\text { \%Pore- } \\
\text { Filling } \\
\text { Berthierine }\end{array}$ & $\begin{array}{l}\text { \%Replacive } \\
\text { Berthierine }\end{array}$ & \%Glauconite \\
\hline PW3 & 1082.3 & 0.7 & 0.3 & 0.0 & 0.0 & 0.0 & 0.0 & 0.0 & 0.0 & 0.3 & 0.0 & 0.0 & 0.0 & 0.0 \\
\hline PW3 & 1085.1 & 0.0 & 0.0 & 0.0 & 0.0 & 0.3 & 0.0 & 0.0 & 0.0 & 0.6 & 0.0 & 1.0 & 0.0 & 0.0 \\
\hline PW3 & 1087.5 & 0.9 & 0.0 & 0.0 & 0.0 & 0.0 & 0.0 & 0.0 & 0.0 & 0.0 & 0.0 & 0.0 & 0.0 & 0.0 \\
\hline PW3 & 1088.3 & 0.0 & 1.3 & 0.3 & 0.0 & 0.0 & 0.0 & 0.0 & 0.0 & 0.0 & 0.0 & 6.3 & 0.0 & 0.0 \\
\hline PW3 & 1088.5 & 0.0 & 5.7 & 0.3 & 0.0 & 0.0 & 0.0 & 0.0 & 0.0 & 0.0 & 0.0 & 13.3 & 0.0 & 0.0 \\
\hline PW3 & 1091.4 & 0.3 & 0.0 & 0.0 & 0.0 & 0.0 & 0.0 & 0.0 & 0.0 & 0.0 & 0.0 & 0.3 & 0.0 & 0.0 \\
\hline PW3 & 1091.5 & 0.0 & 0.0 & 0.0 & 0.0 & 0.0 & 0.0 & 0.0 & 0.0 & 0.3 & 0.6 & 0.9 & 0.6 & 0.0 \\
\hline PW3 & 1094.0 & 0.0 & 0.7 & 0.3 & 0.0 & 0.0 & 0.0 & 0.0 & 0.0 & 0.0 & 0.0 & 0.3 & 0.0 & 0.3 \\
\hline PW3 & 1098.3 & 0.0 & 0.0 & 0.0 & 0.0 & 0.3 & 0.0 & 0.0 & 0.0 & 0.0 & 0.0 & 0.3 & 0.0 & 0.3 \\
\hline PW7 & 1122.5 & 0.0 & 0.3 & 0.0 & 0.0 & 0.3 & 0.0 & 0.0 & 0.0 & 0.0 & 0.0 & 2.0 & 0.0 & 0.7 \\
\hline PW7 & 1123.2 & 0.0 & 0.0 & 0.0 & 0.0 & 0.0 & 0.0 & 0.0 & 0.3 & 0.0 & 0.7 & 3.8 & 1.0 & 0.0 \\
\hline PW7 & 1123.3 & 15.4 & 0.0 & 0.0 & 0.0 & 0.0 & 0.0 & 0.0 & 0.0 & 0.0 & 0.0 & 0.0 & 0.0 & 0.0 \\
\hline PW7 & 1124.0 & 0.0 & 0.0 & 0.0 & 0.0 & 0.0 & 0.0 & 0.0 & 0.0 & 0.0 & 0.3 & 1.9 & 0.3 & 0.0 \\
\hline PW7 & 1124.9 & 0.0 & 0.0 & 0.3 & 0.0 & 0.0 & 0.0 & 0.0 & 0.0 & 0.0 & 0.0 & 0.3 & 0.0 & 0.0 \\
\hline PW7 & 1126.0 & 0.0 & 0.0 & 0.0 & 0.0 & 0.0 & 0.0 & 0.0 & 0.0 & 0.0 & 0.0 & 0.3 & 0.0 & 0.0 \\
\hline PW7 & 1130.0 & 0.9 & 0.0 & 0.0 & 0.0 & 0.0 & 0.0 & 0.0 & 0.0 & 0.3 & 0.3 & 0.0 & 0.3 & 0.0 \\
\hline PW7 & 1131.6 & 0.3 & 0.7 & 0.0 & 0.0 & 0.0 & 0.0 & 0.0 & 0.0 & 0.0 & 0.6 & 0.9 & 0.6 & 0.0 \\
\hline PW7 & 1131.7 & 2.3 & 0.0 & 0.0 & 0.0 & 0.0 & 0.0 & 0.0 & 0.0 & 0.7 & 0.0 & 1.6 & 0.0 & 0.0 \\
\hline
\end{tabular}


Table A1. Cont.

\begin{tabular}{|c|c|c|c|c|c|c|c|c|c|c|c|c|c|c|}
\hline Well & $\begin{array}{l}\text { Depth } \\
\text { (m) }\end{array}$ & $\begin{array}{l}\text { Grain } \\
\text { Size } \\
(\mathrm{mm})\end{array}$ & Sorting (Trask) & $\begin{array}{l}\text { \%Quartz } \\
\text { Monocrys- } \\
\text { talline }\end{array}$ & $\begin{array}{l}\text { \%Quartz Poly- } \\
\text { crystalline }\end{array}$ & $\begin{array}{c}\text { \%Quartz } \\
\text { Pore-Filling }\end{array}$ & $\begin{array}{c}\text { \%Extrabasinal- } \\
\text { Chert }\end{array}$ & $\begin{array}{l}\text { \%Extrabasinal- } \\
\text { Quartzite }\end{array}$ & $\begin{array}{l}\text { \%Extrabasinal- } \\
\text { Sandstone }\end{array}$ & $\begin{array}{l}\text { \%Intergranular } \\
\text { Porosity }\end{array}$ & $\begin{array}{c}\text { \%Cement } \\
\text { Dissolution } \\
\text { Porosity }\end{array}$ & $\begin{array}{c}\text { \%Partial } \\
\text { Grain } \\
\text { Dissolution, } \\
\text { Bioclasts }\end{array}$ & $\begin{array}{c}\text { \%Partial } \\
\text { Grain } \\
\text { Dissolution, } \\
\text { Others }\end{array}$ & $\begin{array}{l}\text { \%Fracture } \\
\text { Porosity }\end{array}$ \\
\hline PW7 & 1132.9 & 0.0 & 0.0 & 0.0 & 0.0 & 0.0 & 0.0 & 0.0 & 0.0 & 0.0 & 0.0 & 0.0 & 0.0 & 0.0 \\
\hline PW7 & 1133.0 & 0.3 & 0.3 & 0.6 & 0.0 & 0.0 & 0.0 & 0.0 & 0.0 & 0.0 & 0.0 & 0.0 & 0.0 & 0.0 \\
\hline PW7 & 1134.6 & 0.0 & 7.3 & 1.0 & 0.0 & 0.3 & 0.3 & 0.7 & 0.0 & 0.0 & 0.0 & 1.0 & 0.0 & 0.3 \\
\hline PW7 & 1135.2 & 0.0 & 0.0 & 0.0 & 0.0 & 0.0 & 0.0 & 0.0 & 0.0 & 0.0 & 0.0 & 0.0 & 0.0 & 0.0 \\
\hline PW7 & 1135.7 & 0.0 & 10.0 & 0.0 & 0.0 & 0.0 & 0.7 & 0.0 & 0.0 & 0.0 & 0.0 & 0.0 & 0.0 & 0.0 \\
\hline PW7 & 1136.5 & 0.0 & 4.6 & 0.0 & 0.0 & 0.0 & 0.0 & 0.0 & 0.0 & 0.0 & 0.0 & 0.3 & 0.0 & 0.0 \\
\hline PW7 & 1137.4 & 0.0 & 4.5 & 0.0 & 0.0 & 0.0 & 3.3 & 1.3 & 0.0 & 0.0 & 0.0 & 0.6 & 0.0 & 0.7 \\
\hline BL5 & 2194.7 & 0.0 & 2.3 & 0.0 & 0.0 & 0.0 & 0.0 & 0.0 & 0.0 & 0.0 & 0.0 & 0.7 & 0.0 & 0.0 \\
\hline BL5 & 2197.9 & 0.0 & 0.3 & 0.0 & 0.0 & 0.0 & 0.0 & 0.0 & 0.0 & 0.0 & 0.0 & 0.0 & 0.0 & 0.0 \\
\hline BL5 & 2198.8 & 0.0 & 0.7 & 1.3 & 0.0 & 0.0 & 0.0 & 0.0 & 0.0 & 0.0 & 0.0 & 0.7 & 0.0 & 0.3 \\
\hline BL5 & 2199.1 & 0.0 & 0.7 & 0.0 & 0.0 & 0.0 & 0.3 & 0.0 & 0.0 & 0.0 & 0.0 & 2.5 & 0.0 & 0.7 \\
\hline BL5 & 2199.5 & 0.0 & 6.3 & 0.0 & 0.3 & 0.3 & 0.0 & 0.0 & 0.0 & 0.0 & 0.0 & 4.0 & 0.0 & 0.0 \\
\hline BL5 & 2199.9 & 0.0 & 1.3 & 0.0 & 0.3 & 3.3 & 0.0 & 0.0 & 0.0 & 2.7 & 0.0 & 3.6 & 0.0 & 0.0 \\
\hline BL5 & 2201.0 & 0.0 & 0.3 & 0.0 & 0.0 & 0.3 & 0.0 & 0.0 & 0.7 & 0.0 & 0.0 & 11.3 & 0.7 & 0.3 \\
\hline BL5 & 2201.9 & 0.6 & 0.0 & 0.0 & 0.0 & 0.0 & 0.0 & 0.0 & 0.0 & 0.0 & 0.3 & 0.3 & 0.3 & 0.0 \\
\hline BL5 & 2202.2 & 0.7 & 0.0 & 0.3 & 0.0 & 0.3 & 0.0 & 0.0 & 0.7 & 0.0 & 0.7 & 0.0 & 1.4 & 0.0 \\
\hline BL5 & 2204.7 & 0.0 & 2.0 & 0.7 & 0.0 & 0.0 & 0.0 & 0.0 & 0.0 & 0.0 & 0.0 & 3.6 & 0.0 & 0.0 \\
\hline BL5 & 2205.8 & 0.0 & 22.0 & 0.3 & 0.7 & 5.0 & 0.0 & 0.3 & 0.0 & 0.0 & 0.0 & 1.3 & 0.0 & 0.0 \\
\hline BL5 & 2206.6 & 0.0 & 11.7 & 0.3 & 0.3 & 0.3 & 0.0 & 0.0 & 0.0 & 0.0 & 0.0 & 1.3 & 0.0 & 0.3 \\
\hline BL5 & 2206.9 & 0.0 & 12.0 & 1.0 & 1.7 & 3.3 & 1.0 & 0.0 & 0.0 & 0.0 & 0.0 & 3.7 & 0.0 & 0.0 \\
\hline BL5 & 2207.1 & 0.0 & 10.3 & 0.3 & 0.3 & 0.3 & 0.0 & 0.0 & 0.0 & 0.0 & 0.0 & 7.0 & 0.0 & 0.0 \\
\hline BL5 & 2209.2 & 0.0 & 3.9 & 0.0 & 0.0 & 0.0 & 0.0 & 0.3 & 0.0 & 0.0 & 0.0 & 1.0 & 0.0 & 0.3 \\
\hline BL5 & 2209.5 & 0.0 & 1.0 & 0.0 & 0.0 & 0.0 & 0.0 & 0.0 & 0.0 & 0.0 & 0.0 & 1.0 & 0.0 & 0.0 \\
\hline BL5 & 2210.4 & 1.0 & 0.3 & 0.7 & 0.0 & 0.0 & 0.3 & 0.0 & 0.0 & 0.0 & 0.0 & 0.0 & 0.0 & 0.0 \\
\hline BL5 & 2211.4 & 0.0 & 2.3 & 0.0 & 0.0 & 0.0 & 0.0 & 0.0 & 0.3 & 0.0 & 0.0 & 1.0 & 0.3 & 0.0 \\
\hline BL5 & 2211.6 & 0.0 & 2.0 & 0.0 & 0.0 & 0.0 & 0.3 & 0.0 & 0.0 & 0.0 & 0.0 & 0.3 & 0.0 & 0.0 \\
\hline BL5 & 2211.6 & 0.0 & 1.7 & 0.0 & 0.0 & 0.0 & 0.3 & 0.0 & 0.0 & 0.0 & 0.0 & 2.3 & 0.0 & 0.0 \\
\hline & Mean & 0.49 & 2.70 & 0.21 & 0.08 & 0.30 & 0.14 & 0.06 & 0.04 & 0.10 & 0.1 & 1.7 & 0.1 & 0.1 \\
\hline Well & $\begin{array}{l}\text { Depth } \\
\text { (m) }\end{array}$ & $\begin{array}{l}\text { \%Pore- } \\
\text { Filling } \\
\text { Pyrite }\end{array}$ & $\begin{array}{l}\text { \%Replacive } \\
\text { Pyrite }\end{array}$ & $\begin{array}{c}\text { \%Apatite } \\
\text { Pore-Filling }\end{array}$ & $\begin{array}{l}\text { \%Apatite } \\
\text { Detrital }\end{array}$ & $\begin{array}{l}\text { \%Others } \\
\text { Pore-Filling }\end{array}$ & $\begin{array}{c}\text { \%Organic } \\
\text { Material }\end{array}$ & $\begin{array}{l}\text { \%Extrabasinal- } \\
\text { Mudstone }\end{array}$ & \%Matrix & $\begin{array}{l}\text { \%Pore- } \\
\text { Filling } \\
\text { Cements }\end{array}$ & \multicolumn{2}{|c|}{ IGV(PMc) } & $\begin{array}{l}\text { CEPL } \\
\text { (House- } \\
\text { knecht) }\end{array}$ & COPL \\
\hline PW3 & 1082.3 & 1.0 & 0.0 & 1.0 & 0.3 & 0.0 & 0.0 & 0.0 & 2.0 & 39.7 & \multicolumn{2}{|c|}{39.7} & 94.5 & 5.5 \\
\hline PW3 & 1085.1 & 0.0 & 0.0 & 0.0 & 0.3 & 0.0 & 0.3 & 0.0 & 0.3 & 39.1 & \multicolumn{2}{|c|}{41.7} & 93.0 & 0.8 \\
\hline PW3 & 1087.5 & 0.3 & 0.0 & 0.0 & 0.0 & 0.0 & 0.0 & 0.0 & 0.3 & 32.7 & \multicolumn{2}{|c|}{34.0} & 77.8 & 19.1 \\
\hline PW3 & 1088.3 & 0.7 & 0.0 & 2.3 & 0.3 & 0.3 & 0.3 & 0.0 & 29.4 & 30.4 & \multicolumn{2}{|c|}{31.0} & 72.3 & 26.3 \\
\hline PW3 & 1088.5 & 1.3 & 0.0 & 0.3 & 0.0 & 0.0 & 0.0 & 0.0 & 30.7 & 26.9 & \multicolumn{2}{|c|}{$\begin{array}{l}29.9 \\
35.4\end{array}$} & 64.1 & 28.7 \\
\hline PW3 & 1091.4 & 0.0 & 0.0 & 0.0 & 0.3 & 0.0 & 0.0 & 0.0 & 0.0 & 34.4 & \multicolumn{2}{|c|}{35.4} & 81.8 & 15.8 \\
\hline PW3 & 1091.5 & 0.7 & 0.0 & 0.0 & 0.0 & 0.6 & 0.0 & 0.0 & 0.0 & 32.6 & \multirow{2}{*}{\multicolumn{2}{|c|}{$\begin{array}{l}35.3 \\
31.8\end{array}$}} & 77.7 & 15.9 \\
\hline PW3 & 1094.0 & 0.3 & 0.0 & 0.0 & 0.0 & 2.0 & 0.0 & 0.0 & 0.0 & 30.1 & & & 71.5 & 24.4 \\
\hline
\end{tabular}


Table A1. Cont.

\begin{tabular}{|c|c|c|c|c|c|c|c|c|c|c|c|c|c|c|}
\hline Well & $\begin{array}{l}\text { Depth } \\
\text { (m) }\end{array}$ & $\begin{array}{l}\text { Grain } \\
\text { Size } \\
(\mathrm{mm})\end{array}$ & Sorting (Trask) & $\begin{array}{c}\text { \%Quartz } \\
\text { Monocrys- } \\
\text { talline }\end{array}$ & $\begin{array}{l}\text { \%Quartz Poly- } \\
\text { crystalline }\end{array}$ & $\begin{array}{c}\text { \%Quartz } \\
\text { Pore-Filling }\end{array}$ & $\begin{array}{l}\text { \%Extrabasinal- } \\
\text { Chert }\end{array}$ & $\begin{array}{l}\text { \%Extrabasinal- } \\
\text { Quartzite }\end{array}$ & $\begin{array}{l}\text { \%Extrabasinal- } \\
\text { Sandstone }\end{array}$ & $\begin{array}{l}\text { \%Intergranular } \\
\text { Porosity }\end{array}$ & $\begin{array}{l}\text { \%Cement } \\
\text { Dissolution } \\
\text { Porosity }\end{array}$ & $\begin{array}{c}\text { \%Partial } \\
\text { Grain } \\
\text { Dissolution, } \\
\text { Bioclasts }\end{array}$ & $\begin{array}{l}\text { \%Partial } \\
\text { Grain } \\
\text { Dissolution, } \\
\text { Others }\end{array}$ & $\begin{array}{c}\text { \%Fracture } \\
\text { Porosity }\end{array}$ \\
\hline PW3 & 1098.3 & 3.3 & 0.0 & 0.0 & 0.0 & 1.3 & 0.0 & 0.0 & 61.1 & 17.2 & 17.5 & & 41.0 & 58.2 \\
\hline $\begin{array}{l}\text { PW7 } \\
\text { Pan }\end{array}$ & 1122.5 & 2.3 & 0.0 & 0.0 & 0.0 & 0.3 & 0.0 & 0.0 & 23.9 & 47.1 & 47.1 & & 112.1 & -12.1 \\
\hline PW7 & 1123.2 & 14.8 & 1.0 & 0.0 & 0.0 & 1.0 & 0.0 & 0.0 & 0.0 & 34.9 & 42.0 & & 83.2 & 0.1 \\
\hline PW7 & 1123.3 & 2.0 & 1.0 & 0.0 & 0.0 & 0.0 & 0.0 & 0.0 & 16.0 & 22.9 & 27.0 & & 54.6 & 35.8 \\
\hline $\begin{array}{l}\text { PW7 } \\
\text { PW }\end{array}$ & $\begin{array}{l}1124.0 \\
\end{array}$ & 0.0 & 0.0 & 0.0 & 0.0 & 0.0 & 0.0 & 0.0 & $\begin{array}{l}0.0 \\
0.0\end{array}$ & 25.3 & 30.1 & & 60.3 & 28.5 \\
\hline PW7 & 1124.9 & 0.0 & 0.0 & 0.0 & 0.0 & 0.0 & 0.0 & 0.3 & 0.0 & 39.8 & 40.8 & & 94.9 & 2.7 \\
\hline PW7 & 1126.0 & 0.3 & 0.0 & 0.0 & 0.0 & 0.0 & 0.0 & 0.0 & 0.0 & 14.8 & 39.7 & & 35.2 & 5.5 \\
\hline PW7 & 1130.0 & 0.0 & 0.0 & 0.0 & 0.0 & 0.0 & 0.0 & 0.0 & 0.7 & 39.5 & 39.8 & & 94.0 & 5.2 \\
\hline $\begin{array}{l}\text { PW7 } \\
\text { Pat }\end{array}$ & 1131.7 & 0.0 & 0.3 & 0.0 & 0.0 & 0.0 & 0.3 & 0.0 & 0.0 & 18.9 & 30.2 & & 44.9 & 28.0 \\
\hline $\begin{array}{l}\text { PW7 } \\
\text { Pat }\end{array}$ & 1132.9 & 0.0 & 0.0 & 0.0 & 0.0 & 0.0 & 0.0 & 0.0 & 0.0 & 39.8 & 42.5 & & 94.7 & -1.1 \\
\hline PW7 & 1133.0 & 0.3 & 0.0 & 0.0 & 0.3 & 0.0 & 0.0 & 0.0 & 0.0 & 43.6 & 43.6 & & 103.9 & -3.9 \\
\hline PW7 & 1134.6 & 1.0 & 0.0 & 0.0 & 0.0 & 1.3 & 0.0 & 0.0 & 18.8 & 19.0 & 25.4 & & 45.2 & 39.5 \\
\hline $\begin{array}{l}\text { PW7 } \\
\text { PW }\end{array}$ & $\begin{array}{r}1135.0 \\
\end{array}$ & 0.3 & 0.0 & 0.0 & 0.0 & 0.0 & 0.0 & 0.0 & $\begin{array}{c}10.0 \\
0.0\end{array}$ & 29.4 & 31.4 & & $\begin{array}{l}70.2 \\
70.0\end{array}$ & 25.3 \\
\hline PW7 & 1135.7 & 1.7 & 0.0 & 0.0 & 0.0 & 2.3 & 0.0 & 0.0 & 13.7 & 21.3 & 35.4 & & 50.8 & 15.8 \\
\hline PW7 & 1136.5 & 1.0 & 0.0 & 0.0 & 0.0 & 0.0 & 0.3 & 0.0 & 0.0 & 13.2 & 32.9 & & 31.4 & 21.7 \\
\hline PW7 & 1137.4 & 2.0 & 0.0 & 0.0 & 0.0 & 0.7 & 0.0 & 0.0 & 0.7 & 18.5 & 39.8 & & 43.9 & 5.2 \\
\hline BL5 & 2194.7 & 2.0 & 0.0 & 0.3 & 0.3 & 0.0 & 0.0 & 0.0 & 2.3 & 38.3 & 38.6 & & 91.3 & 8.0 \\
\hline BL5 & 2195.2 & 1.3 & 0.0 & 0.0 & 0.0 & 0.0 & 1.0 & 0.0 & 6.3 & 44.7 & 44.7 & & 106.5 & -6.5 \\
\hline BL5 & 2197.9 & 2.7 & 0.0 & 0.0 & 0.0 & 0.0 & 0.0 & 0.0 & 13.3 & 45.8 & 46.1 & & 109.0 & -9.8 \\
\hline BL5 & 2198.8 & 1.7 & 0.0 & 0.0 & 0.0 & 0.0 & 0.0 & 0.0 & 0.0 & 35.9 & 36.5 & & 85.5 & 13.1 \\
\hline BL5 & 2199.1 & 1.7 & 0.0 & 0.0 & 0.0 & 0.0 & 0.3 & 0.0 & 0.3 & 21.2 & 35.6 & & 50.4 & 15.1 \\
\hline BL5 & 2201.0 & 0.7 & 0.0 & 0.0 & 0.0 & 0.7 & 0.0 & 0.0 & 38.1 & 28.4 & 28.4 & & 67.5 & 32.5 \\
\hline BL5 & 2201.9 & 0.0 & 0.3 & 0.0 & 1.0 & 0.0 & 0.0 & 0.0 & 0.0 & 34.6 & 37.3 & & 82.5 & 11.1 \\
\hline BL5 & 2202.2 & 0.0 & 0.0 & 0.0 & 0.0 & 0.3 & 0.0 & 0.0 & 0.3 & 31.0 & 33.6 & & $\begin{array}{l}73.9 \\
73.0\end{array}$ & 19.9 \\
\hline BL5 & 2204.7 & 1.0 & 0.0 & 0.0 & 0.0 & 0.0 & 0.0 & 0.0 & 0.0 & 18.7 & 33.1 & & 44.5 & 21.1 \\
\hline BL5 & 2205.8 & 0.7 & 0.0 & 0.0 & 0.0 & 0.0 & 0.0 & 0.0 & 4.7 & 32.7 & 36.0 & & 77.9 & 14.2 \\
\hline BL5 & 2206.6 & 0.3 & 0.3 & 0.0 & 0.0 & 0.0 & 0.0 & 0.0 & 10.0 & 43.1 & 43.8 & & 102.7 & -4.4 \\
\hline BL5 & 2206.9 & 3.6 & 0.0 & 0.0 & 0.0 & 0.3 & 0.0 & 0.0 & 19.7 & 25.6 & 25.6 & & 61.0 & 39.0 \\
\hline BL5 & 2207.1 & 1.3 & 1.3 & 0.0 & 0.7 & 0.0 & 0.0 & 0.0 & 16.4 & 25.3 & 25.6 & & 60.2 & 39.0 \\
\hline BL5 & 2208.0 & 1.0 & 0.0 & 0.0 & 0.0 & 0.0 & 0.0 & 0.0 & 13.4 & 16.3 & 25.3 & & 38.9 & 39.8 \\
\hline BL5 & 2208.9 & 0.3 & 0.0 & 0.0 & 0.0 & 0.0 & 0.0 & 0.0 & 0.0 & 40.7 & 41.4 & & 96.9 & 1.4 \\
\hline BL5 & 2209.2 & 0.0 & 0.0 & 0.0 & 0.0 & 0.0 & 0.0 & 0.0 & 1.0 & 20.3 & 33.4 & & 48.3 & 20.6 \\
\hline BL5 & 2209.5 & 0.0 & 0.0 & 0.0 & 0.0 & 0.0 & 0.3 & 0.0 & 0.3 & 11.3 & 28.4 & & $\begin{array}{l}\text { to. } \\
27.0\end{array}$ & 32.3 \\
\hline BL5 & 2210.4 & 1.0 & 0.0 & 0.0 & 0.0 & 1.0 & 0.0 & 0.0 & 2.7 & 28.0 & 32.3 & & 66.7 & 23.0 \\
\hline BL5 & 2211.4 & 1.3 & 0.3 & 0.0 & 0.0 & 1.3 & 1.6 & 0.0 & 0.0 & 13.8 & 31.3 & & 32.8 & 25.5 \\
\hline BL5 & 2211.6 & 0.0 & 0.0 & 0.0 & 0.0 & 0.3 & 0.7 & 0.0 & 2.9 & 16.4 & 25.0 & & 39.0 & 40.5 \\
\hline \multirow[t]{2}{*}{ BL5 } & 2211.6 & 0.7 & 0.0 & 0.0 & 0.0 & 1.3 & 1.6 & 0.0 & 0.0 & 17.6 & 32.9 & & 41.8 & 21.6 \\
\hline & Mean & 1.3 & 0.1 & 0.1 & 0.1 & 0.4 & 0.1 & 0.0 & 7.0 & 29.7 & 35.4 & & 70.7 & 15.7 \\
\hline
\end{tabular}




\section{References}

1. Burley, S.; Worden, R.H. Sandstone Diagenesis: Recent and Ancient, 1st ed.; International Association of Sedimentologists, Blackwell Publishing Ltd.: Oxford, UK, 2003; Volume 24.

2. Wilson, M.D.; Stanton, P.T. Diagenetic Mechanisms of Porosity and Permeability Reduction and Enhancement. Reserv. Qual. Assess. Predict. Clastic Rocks 1994, 1994, 59-118.

3. Byrnes, A.P. Empirical methods of reservoir quality prediction. In Reservoir Quality Assessment and Prediction in Clastic Rocks; Wilson, M.D., Ed.; SEPM (Society for Sedimentary Geology) Short Course 30: Tulsa, OK, USA, 1994; pp. 9-21.

4. Bloch, S.; McGowen, J.H.; Wilson, M.D. Influence of Depositional Environment on Reservoir Quality Prediction. In Reservoir Quality Assessment and Prediction in Clastic Rocks; SEPM (Society for Sedimentary Geology): Tulsa, OK, USA, $1994 ;$ pp. $41-57$.

5. Worden, R.H.; Armitage, P.J.; Butcher, A.; Churchill, J.M.; Csoma, A.E.; Hollis, C.; Lander, R.H.; Omma, J.E. Petroleum reservoir quality prediction: Overview and contrasting approaches from sandstone and carbonate communities. Geol. Soc. Lond. Spec. Publ. 2018, 435, 1-31. [CrossRef]

6. Trueman, S. The Humbly Grove, Herriard, Storrington, Singleton, Stockbridge, Goodworth, Horndean, Palmers Wood, Bletchingley and Albury Fields, Hampshire, Surrey and Sussex, UK Onshore. In United Kingdom Oil and Gas Fields; Commemorative Millennium Volume; Gluyas, J.G., Hichens, H.M., Eds.; Geological Society, Memoirs: London, UK, 2003 ; pp. 929-941.

7. Andrews, I. The Jurassic Shales of the Weald Basin: Geology and Shale Oil and Shale Gas. Resource Estimation; DECC, Ed.; British Geological Survey: London, UK, 2014; pp. 1-79.

8. Pullan, C.P.; Butler, M. Paleozoic gas potential in the Weald Basin of southern England. Geol. Soc. Lond. Spéc. Publ. 2019, 471, 333-363. [CrossRef]

9. Hawkes, P.W.; Fraser, A.J.; Einchcomb, C.C.G. The tectono-stratigraphic development and exploration history of the Weald and Wessex basins, Southern England, UK. Geol. Soc. Lond. Spéc. Publ. 1998, 133, 39-65. [CrossRef]

10. Arkell, W.J. The Jurassic System in Great Britain. Geogr. J. 1934, 84, 85. [CrossRef]

11. De Wet, C.B. Deciphering the sedimentological expression of tectonics, eustasy, and climate: A basinwide study of the Corallian Formation, southern England. J. Sediment. Res. 1998, 68, 653-667. [CrossRef]

12. Sun, S.Q. A storm-dominated offshore sandstone interval from the Corallian Group (Upper Jurassic), Weald Basin, southern England. Mar. Pet. Geol. 1992, 9, 274-286. [CrossRef]

13. Hillis, R.R.; Holford, S.P.; Green, P.F.; Doré, A.G.; Gatliff, R.W.; Stoker, M.S.; Thomson, K.; Turner, J.P.; Underhill, J.R.; Williams, G.A. Cenozoic exhumation of the southern British Isles. Geology 2008, 36, 371. [CrossRef]

14. Hansen, D.L.; Blundell, D.J.; Nielsen, S.B. A Model for the Evolution of the Weald Basin; Bulletin of the Geological Society of Denmark: Copenhagen, Denmark, 2002; Volume 49, Part 2; pp. 109-118.

15. Sellwood, B.; Scott, J.; Lunn, G. Mesozoic basin evolution in Southern England. Proc. Geol. Assoc. 1986, 97, 259-289. [CrossRef]

16. Bloch, S.; Wilson, M.D. Importance of Reservoir Quality Prediction in Exploration. In Reservoir Quality Assessment and Prediction in Clastic Rocks; Michael, W.D., Ed.; SEPM (Society for Sedimentary Geology): Tulsa, OK, USA, 1994; pp. 5-9.

17. Gier, S.; Worden, R.H.; Krois, P. Comparing clay mineral diagenesis in interbedded sandstones and mudstones, Vienna Basin, Austria. Geol. Soc. Lond. Spéc. Publ. 2018, 435, 389-403. [CrossRef]

18. Kupecz, J.A.; Gluyas, J.; Bloch, S. Reservoir Quality Prediction in Sandstones and Carbonates. Reserv. Qual. Predict. Sandstones Carbonates 1997, 69. [CrossRef]

19. Butler, M.; Pullan, C.P. Tertiary structures and hydrocarbon entrapment in the Weald Basin of southern England. Geol. Soc. Lond. Spéc. Publ. 1990, 55, 371-391. [CrossRef]

20. Lake, S.D.; Karner, G.D. The structure and evolution of the Wessex Basin, southern England: An example of inversion tectonics. Tectonophysics 1987, 137, 347-378. [CrossRef]

21. McLimans, R.K.; Videtich, P.E. Diagenesis and Burial History of Great Oolite Limestone, Southern England1. AAPG (Am. Assoc. Pet. Geol.) Bull. 1989, 73, 1195-1205.

22. Talbot, M. Major sedimentary cycles in the corallian beds (Oxfordian) of Southern England. Palaeogeogr. Palaeoclim. Palaeoecol. 1973, 14, 293-317. [CrossRef]

23. Radley, J.D. A Wealden guide I: The Weald Sub-basin. Geol. Today 2006, 22, 109-118. [CrossRef]

24. Jones, D.K. On the uplift and denudation of the Weald. In Uplift, Erosion and Stability: Perspectives on Long-Term Landscape Development; Smith, B.J., Whalley, B.W., Warke, P.A., Eds.; Geological Society, London, Special Publications: London, UK, 1999; pp. $25-43$.

25. Ebukanson, E.J.; Kinghorn, R.R.F. Oil and gas accumulations and their possible source rocks in southern England. J. Pet. Geol. 1986, 9, 413-427. [CrossRef]

26. Palci, F. Unconventional Hydrocarbon Potential of the Weald Basin, Southern England, United Kingdom. In AAPG (Am. Assoc. Pet. Geol.) ACE 2018; American Association of Petroleum Geologists: Salt Lake City, UT, USA, 2018.

27. Hampson, G.; Storms, J. Geomorphological and sequence stratigraphic variability in wave-dominated, shoreface-shelf parasequences. Sedimentology 2008, 50, 667-701. [CrossRef]

28. Pemberton, S.G.; MacEachern, J.A.; Dashtgard, S.E.; Bann, K.L.; Gingras, M.K.; Zonneveld, J.P. Shorefaces. In Trace Fossils as Indicators of Sedimentary Environments; Knaust, D., Bromley, R.G., Eds.; Elsevier: Amsterdam, The Netherland, 2012 ; pp. 563-603. 
29. Rider, M.H. The Geological Interpretation of Well Logs; John Wiley and Sons, Inc.: Hoboken, NJ, USA, 1986.

30. Worden, R.H.; Utley, J.E.P.; Butcher, A.R.; Griffiths, J.; Wooldridge, L.J.; Lawan, A.Y. Improved imaging and analysis of chlorite in reservoirs and modern day analogues: New insights for reservoir quality and provenance. Geol. Soc. Lond. Spéc. Publ. 2020, 484, 189-204. [CrossRef]

31. Armitage, P.J.; Faulkner, D.; Worden, R.H.; Aplin, A.; Butcher, A.; Iliffe, J. Experimental measurement of, and controls on, permeability and permeability anisotropy of caprocks from the CO2storage project at the Krechba Field, Algeria. J. Geophys. Res. Space Phys. 2011, 116, B12. [CrossRef]

32. Armitage, P.; Worden, R.H.; Faulkner, D.; Aplin, A.; Butcher, A.; Iliffe, J. Diagenetic and sedimentary controls on porosity in Lower Carboniferous fine-grained lithologies, Krechba field, Algeria: A petrological study of a caprock to a carbon capture site. Mar. Pet. Geol. 2010, 27, 1395-1410. [CrossRef]

33. Pirrie, D.; Butcher, A.R.; Power, M.R.; Gottlieb, P.; Miller, G.L. Rapid quantitative mineral and phase analysis using automated scanning electron microscopy (QemSCAN): Potential applications in forensic geoscience. In Forensic Geoscience: Principles, Techniques and Applications; Pye, K., Croft, D.J., Eds.; Geological Society: Bath, UK, 2004; pp. 123-136.

34. Wooldridge, L.J.; Worden, R.H.; Griffiths, J.; Utley, J.E.; Thompson, A. The origin of clay-coated sand grains and sediment heterogeneity in tidal flats. Sediment. Geol. 2018, 373, 191-209. [CrossRef]

35. Chung, F.H. Quantitative interpretation of X-ray diffraction patterns of mixtures. I. Matrix-flushing method for quantitative multicomponent analysis. J. Appl. Crystallogr. 1974, 7, 519-525. [CrossRef]

36. The British Geological Survey. The BGS Lexicon of Named Rock Units. 2020. Available online: https://www.bgs.ac.uk/ technologies / the-bgs-lexicon-of-named-rock-units / (accessed on 24 June 2021).

37. McBride, E. A Classification of Common Sandstones. J. Sediment. Res. 1963, 33, 664-669.

38. Ramm, M.; Forsberg, A.W.; Jahren, J.S. Porosity-Depth Trends in Deeply Buried Upper Jurassic Reservoirs in the Norwegian Central Graben: An Example of Porosity Preservation Beneath the Normal Economic Basement by Grain-Coating Microquartz. In Reservoir Quality Prediction in Sandstones and Carbonates; Kupecz, J.A., Gluyas, J.G., Bloch, S., Eds.; American Association of Petroleum Geologists: Tulsa, OK, USA, 1997; pp. 177-200.

39. Emery, D.; Myers, K.J.; Young, R. Ancient subaerial exposure and freshwater leaching in sandstones. Geology 1990, 18, $1178-1181$. [CrossRef]

40. Glasmann, J.R. The fate of feldspar in Brent Group reservoirs, North Sea: A regional synthesis of diagenesis in shallow, intermediate, and deep burial environments. Geol. Soc. Lond. Spéc. Publ. 1992, 61, 329-350. [CrossRef]

41. Scholle, P.A.; Ulmer-Scholle, D.S. A Color Guide to the Petrography of Carbonate Rocks: Grains, Textures, Porosity, Diagenesis; American Association of Petroleum Geologists Memoir: Tulsa, OK, USA, 2003; Volume 77.

42. Adams, A.; Mackenzie, W.S. Carbonate Sediments and Rocks Under the Microscope: A Colour Atlas; Manson Publishing Ltd.: London, UK, 1998.

43. Goldhaber, M.B. Sulfur-rich Sediments. In Treatise on Geochemistry; Mackenzie, F.T., Ed.; Elsevier: Amsterdam, The Netherlands, 2003; pp. 257-289.

44. Rahman, M.J.J.; Worden, R.H. Diagenesis and its impact on the reservoir quality of Miocene sandstones (Surma Group) from the Bengal Basin, Bangladesh. Mar. Pet. Geol. 2016, 77, 898-915. [CrossRef]

45. Houseknecht, D.W. Assessing the Relative Importance of Compaction Processes and Cementation to Reduction of Porosity in Sandstones. AAPG (Am. Assoc. Pet. Geol.) Bull. 1987, 71, 633-642. [CrossRef]

46. Berner, R.A. Stability Fields of Iron Minerals in Anaerobic Marine Sediments. J. Geol. 1964, 72, 826-834. [CrossRef]

47. Tucker, M. Sedimentary Petrology: An Introduction; Blackwell Scientific Publications: Oxford, UK, 1981; Volume 3, 252p.

48. Pettijohn, F.J.; Potter, P.E.; Siever, R. Sand and Sandstone; Springer: New York, NY, USA, 1973; 618p.

49. Macquaker, J.H.S.; Taylor, K.G.; Young, T.; Curtis, C.D. Sedimentological and geochemical controls on ooidal ironstone and 'bonebed' formation and some comments on their sequence-stratigraphical significance. Geol. Soc. Lond. Spéc. Publ. 1996, 103, 97-107. [CrossRef]

50. Ruttenberg, K.C.; Berner, R.A. Authigenic apatite formation and burial in sediments from non-upwelling, continental margin environments. Geochim. Cosmochim. Acta 1993, 57, 991-1007. [CrossRef]

51. Fritz, S.J.; Toth, T.A. An Fe-berthierine from a Cretaceous laterite: Part II. Estimation of Eh, $\mathrm{pH}$ and $\mathrm{pCO}_{2}$ conditions of formation. Clays Clay Miner. 1997, 45, 580-586. [CrossRef]

52. Fu, Y.; Van Berk, W.; Schulz, H.-M.; Mu, N. Berthierine formation in reservoir rocks from the Siri oilfield (Danish North Sea) as result of fluid-rock interactions: Part II. Deciphering organic-inorganic processes by hydrogeochemical modeling. Mar. Pet. Geol. 2015, 65, 317-326. [CrossRef]

53. Bhattacharyya, D.P. Origin of Berthierine in Ironstones. Clays Clay Miner. 1983, 31, 173-182. [CrossRef]

54. Williams, M. The development of hiatal surfaces in the Osmington Mills ironstone member of the upper Jurassic ringstead formation of south Dorset, England. Proc. Geol. Assoc. 2003, 114, 193-210. [CrossRef]

55. Worden, R.H.; Morad, S. Clay Minerals in Sandstones: Controls on Formation, Distribution and Evolution. In Clay Mineral Cements in Sandstones; Wiley: Hoboken, NJ, USA, 1999; pp. 1-41.

56. Worden, R.H.; Griffiths, J.; Wooldridge, L.; Utley, J.; Lawan, A.; Muhammed, D.; Simon, N.; Armitage, P. Chlorite in sandstones. Earth-Science Rev. 2020, 204, 103105. [CrossRef] 
57. Aagaard, P.; Jahren, J.S.; Harstad, A.O.; Nilsen, O.; Ramm, M. Formation of grain-coating chlorite in sandstones. Laboratory synthesized vs. natural occurrences. Clay Miner. 2000, 35, 261-269. [CrossRef]

58. Virolle, M.; Brigaud, B.; Beaufort, D.; Patrier, P.; Abdelrahman, E.; Thomas, H.; Portier, E.; Samson, Y.; Bourillot, R.; Féniès, $\mathrm{H}$. Authigenic berthierine and incipient chloritization in shallowly buried sandstone reservoirs: Key role of the source-to-sink context. GSA Bull. 2021, 28. [CrossRef]

59. Scotchman, I.; Johnes, L.; Miller, R. Clay diagenesis and oil migration in Brent Group sandstones of NW Hutton Field, UK North Sea. Clay Miner. 1989, 24, 339-374. [CrossRef]

60. Worden, R.H.; Morrall, G.T.; Kelly, S.; Mc Ardle, P.; Barshep, D.V. A renewed look at calcite cement in marine-deltaic sandstones: The Brent Reservoir, Heather Field, northern North Sea, UK. Geol. Soc. Lond. Spéc. Publ. 2020, 484, 305-335. [CrossRef]

61. Worden, R.H.; Oxtoby, N.H.; Smalley, P. Can oil emplacement prevent quartz cementation in sandstones? Pet. Geosci. 1998, 4, 129-137. [CrossRef]

62. Walderhaug, O. Modelling Quartz Cementation and Porosity in Middle Jurassic Brent Group Sandstones of the Kvitebjørn Field, Northern North Sea. AAPG (Am. Assoc. Pet. Geol.) Bull. 2000, 84, 1325-1339. [CrossRef]

63. Worden, R.H.; Morad, S. Quartz Cementation in Oil Field Sandstones: A Review of the Key Controversies. Quartz Cem. Sandstones 2009, 29, 1-20. [CrossRef]

64. Bjørkum, P.A.; Oelkers, E.H.; Nadeau, P.H.; Walderhaug, O.; Murphy, W.M. Porosity prediction in quartzose sandstones as a function of time, temperature, depth, stylolite frequency, and hydrocarbon saturation. AAPG (Am. Assoc. Pet. Geol.) Bull. 1998, 82, 637-648.

65. Worden, R.H.; Bukar, M.; Shell, P. The effect of oil emplacement on quartz cementation in a deeply buried sandstone reservoir. AAPG (Am. Assoc. Pet. Geol.) Bull. 2018, 102, 49-75. [CrossRef]

66. Walderhaug, O. Temperatures of Quartz Cementation in Jurassic Sandstones from the Norwegian Continental Shelf-Evidence from Fluid Inclusions. J. Sediment. Res. 1994, 64A, 311-323. [CrossRef]

67. Gehring, A.U. Diagenesis of ferriferous phases in the Northampton ironstone in the Cowthick quarry near Corby (England). Geol. Mag. 1990, 127, 169-176. [CrossRef]

68. Ehrenberg, S.; Nadeau, P. Formation of diagenetic illite in sandstones of the Garn Formation, Haltenbanken area, mid-Norwegian continental shelf. Clay Miner. 1989, 24, 233-253. [CrossRef]

69. Orem, W.; Finkelman, R. Coal formation and geochemistry. In Treatise on Geochemistry; Michael, W.D., Ed.; Elsevier: Amsterdam, The Netherlands, 2003; pp. 191-223.

70. Bjørlykke, K. Clay Mineral Diagenesis in Sedimentary Basins-A Key to the Prediction of Rock Properties. Examples from the North Sea Basin. Clay Miner. 1998, 33, 15-34. [CrossRef]

71. Houseknecht, D.W. Influence of Grain Size and Temperature on Intergranular Pressure Solution, Quartz Cementation, and Porosity in a Quartzose Sandstone. J. Sediment. Res. 1984, 54, 348-361. [CrossRef]

72. Bryant, L.D.; Kantorowicz, J.D.; Love, C.F. The origin and recognition of laterally continuous carbonate-cemented horizons in the Upper Lias Sands of southern England. Mar. Pet. Geol. 1988, 5, 108-133. [CrossRef] 